\title{
$80 \begin{aligned} & \text { Sosyal Güvenlik Dergisi } \\ & \text { Journal of Social Security }\end{aligned}$ \\ P-ISSN: 2146-4839 \\ E-ISSN: $2148-483 \mathrm{X}$ \\ Uluslararası İlke ve Standartlar Bağlamında Yaşı Hakları ve Sosyal Hizmet Uygulamaları
}

\section{Elderly Rights and Social Service Practices in the Context of International Principles and Standards}

\section{Nuray GÖKÇEK KARACA}

Anadolu Üniversitesi, Sağlık Bilimleri Fakültesi, Sosyal Hizmet Bölümü

Aralık 2019, Cilt 9, Sayı 2, Sayfa 255-274

December 2019, Volume 9, Issue 2, Page 255-274

P-ISSN: 2146-4839

E-ISSN: 2148-483X

$2019-2$

e-posta: sgd@sgk.gov.tr

Yazılar yayınlanmak üzere kabul edildiği takdirde, SGD elektronik ortamda tam metin olarak yayımlamak da dahil olmak üzere, tüm yayın haklarına sahip olacaktır. Yayınlanan yazılardaki görüşlerin sorumluluğu yazarına aittir. Yazı ve tablolardan kaynak gösterilerek alıntı yapılabilir.

If the manuscripts are accepted to be published, the SGD has the possession of right of publicationand the copyright of the manuscripts, included publishing the whole text in the digital area. Articles published in the journal represent solely the views of the authors.

Some parts of the articles and the tables can be citeded by showing the source. 
Cilt: 9 - Say1: 2 - Y11: 2019

Volume: 9 - Issue: 2 - Year: 2019

P-ISSN: 2146-4839

E-ISSN: 2148-483X

Sahibi / Owner of the Journal

Sosyal Güvenlik Kurumu Adına / On behalf of the Social Security Institution

Dr. Mehmet Selim BAĞLI

(Kurum Başkan1 / President of the Institution)

Sorumlu Yazı İșleri Müdürü / Responsible Publication Manager

Uğur KORKMAZ

Yayın Kurulu / Editorial Board

Cevdet CEYLAN

Eyüp Sabri DEMIRCI

Nazmi DOĞAN

Erdal YILMAZ

Okan AYAZ

Editörler / Editors

Doç. Dr. Erdem CAM

Selda DEMIR

Redaksiyon / Redaction

Nihan ERTÜRK

Yayın Türü: Uluslararası Süreli Yayın / Type of Publication: International Periodical

Yayın Aralığı: 6 aylık / Frequency of Publication: Twice a Year

Dili: Türkçe ve İngilizce / Language: Turkish and English

Basım Tarihi / Press Date: 19.12.2019

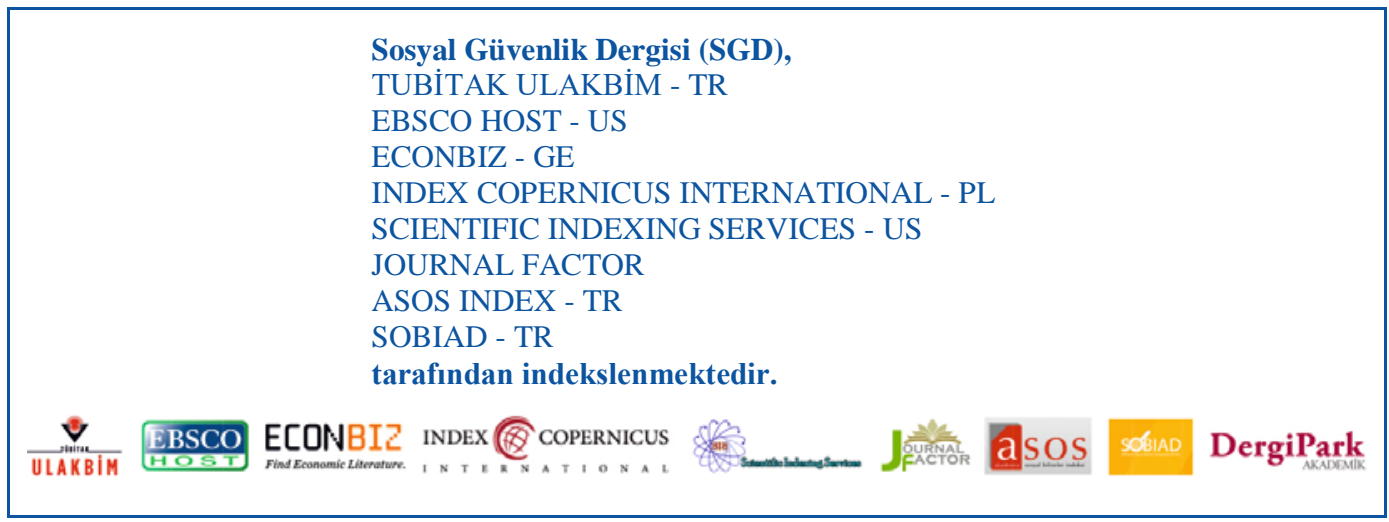

(C) Tüm hakları saklıdır. Sosyal Güvenlik Dergisi'nde yer alan bilimsel çalışmaların bir kısmı ya da tamamı telif hakları saklı kalmak üzere eğitim, araştırma ve bilimsel amaçlarla çoğaltılabilir.

Tasarım / Design: PERSPEKTIF Matbaacılık Tasarım Tic.Ltd.Şti. (0 312) 3842055 - Ankara

Basım Yeri / Printed in: PERSPEKTIF Matbaacılık Tasarım Tic.Ltd.Şti. (0 312) 3842055 - Ankara

İletişim Bilgileri / Contact Information

Sosyal Güvenlik Kurumu Başkanlığı

Ziyabey Caddesi No: 6 Balgat / Ankara / TÜRKIYE

Tel / Phone: +90 3122078891 - 2078770 - Faks / Fax: +90 3122077819

Erişim/Webpage: http://www.sgk.gov.tr/wps/portal/sgk/sgd/tr - e-posta / e-mail: sgd@sgk.gov.tr 
Professor Yener ALTUNBAŞ

Bangor University - UK

Professor Paul Leonard GALLINA

Bishop’s University - CA

Professor Jacqueline S.ISMAEL

University of Calgary - CA
Professor Özay MEHMET

University of Carleton - CA

Professor Allan MOSCOVITCH

University of Carleton - CA

Professor Mark THOMPSON

University of British Columbia - CA
Asst. Prof. Sara HSU

State University of New York- USA

Asst. Prof. C. Rada Von ARNIM

University of Utah - USA

\section{ULUSAL DANISMA KURULU / NATIONAL ADVISORY BOARD}

Prof. Dr. Ahmet Cevat ACAR

İstanbul Üniversitesi

İşletme Fakültesi

Prof. Dr. İsmail AĞIRBAŞ

Ankara Üniversitesi

Sağlık Bilimleri Fakültesi

Prof. Dr. Levent AKIN

Ankara Üniversitesi

Hukuk Fakültesi

Prof. Dr. Yusuf ALPER

Bursa Uludağ Üniversitesi

İktisadi ve İdari Bilimler Fakültesi

Prof. Dr. Faruk ANDAÇ

Çă̆ Üniversitesi

Hukuk Fakültesi

Prof. Dr. Kadir ARICI

Ankara Hacı Bayram Veli Üniversitesi

Hukuk Fakültesi

Prof. Dr. Onur Ender ASLAN

Ankara Sosyal Bilimler Üniversitesi

Siyasal Bilgiler Fakültesi

Prof. Dr. Zakir AVȘAR

Ankara Hacı Bayram Veli Üniversitesi

İletișim Fakültesi

Prof. Dr. Ufuk AYDIN

Anadolu Üniversitesi

Hukuk Fakültesi

Prof. Dr. Abdurrahman AYHAN

Kıbrıs İlim Üniversitesi

Hukuk Fakültesi

Prof. Dr. Serpil AYTAC

Bursa Uludağ Üniversitesi

İktisadi ve İdari Bilimler Fakültesi

Prof. Dr. Mehmet BARCA

Ankara Sosyal Bilimler Üniversitesi

Siyasal Bilgiler Fakültesi

Prof. Dr. Süleyman BAȘTERZI

Ankara Üniversitesi

Hukuk Fakültesi

Prof. Dr. Nursen CANIKLİOĞLU

Marmara Üniversitesi

Hukuk Fakültesi

Prof. Dr. Fevzi DEMIR

Yaşar Universitesi

Hukuk Fakültesi
Prof. Dr. A. Murat DEMIRCIOĞLU

Yıldız Teknik Üniversitesi

İktisadi ve İdari Bilimler Fakültesi

Prof. Dr. Ömer EKMEKÇİ

İstanbul Üniversitesi

Hukuk Fakültesi

Prof. Dr. E. Murat ENGIiN

Galatasaray Üniversitesi

Hukuk Fakültesi

Prof. Dr. Hediye ERGIN

Marmara Üniversitesi

İktisat Fakültesi

Prof. Dr. Sükran ERTÜRK

Dokuz Eylül Üniversitesi

Hukuk Fakültesi

Prof. Dr. Afsun Ezel ESATOĞLU

Ankara Üniversitesi

Sağlık Bilimleri Fakültesi

Prof. Dr. Ali GÜZEL

Kadir Has Üniversitesi

Hukuk Fakültesi

Prof. Dr. Alpay HEKIMLER

Tekirdağ Namık Kemal Üniversitesi

İktisadi ve İdari Bilimler Fakültesi

Prof. Dr. Oğuz KARADENIZ

Pamukkale Üniversitesi

İktisadi ve İdari Bilimler Fakültesi

Prof. Dr. Aşkın KESER

Bursa Uludağ Üniversitesi

İktisadi ve İdari Bilimler Fakültesi

Prof. Dr. Cem KILIC

TOBB Ekonomi ve Teknoloji Üniversites İktisadi ve İdari Bilimler Fakültesi

Prof. Dr. Ali Riza OKUR

İstanbul Sabahattin Zaim Üniversitesi Hukuk Fakültesi

Prof. Dr. Serdar SAYAN

TOBB Ekonomi ve Teknoloji Üniversitesi

İktisadi ve İdari Bilimler Fakültesi

Prof. Dr. Ali Nazım SÖZER

Yaşar Üniversitesi

Hukuk Fakültesi

Prof. Dr. Sarper SÜZEK

At1lım Universites

Hukuk Fakültesi
Prof. Dr. Müjdat SAKAR

Marmara Üniversitesi

İktisat Fakültes

Prof. Dr. Savas TASSKENT

İstanbul Teknik Üniversitesi

İşletme Fakültesi

Prof. Dr. Ferda YERDELEN TATOĞLU

İstanbul Üniversitesi

İktisat Fakültesi

Prof. Dr. Sabri TEKIR

İzmir Demokrasi Üniversitesi

İktisadi ve İdari Bilimler Fakültesi

Prof. Dr. Mehmet TOP

Hacettepe Üniversitesi

İktisadi ve İdari Bilimler Fakültesi

Prof. Dr. Türker TOPALHAN

Ankara Hacı Bayram Veli Üniversitesi

İktisadi ve İdari Bilimler Fakültesi

Prof. Dr. Aziz Can TUNCAY

Bahçeșehir Üniversitesi

Hukuk Fakültesi

Prof. Dr. M. Fatih UȘAN

Ankara Yıldırım Beyazıt Üniversitesi

Hukuk Fakültesi

Doç. Dr. Gaye BAYCIK

Ankara Üniversitesi

Hukuk Fakültesi

Doc. Dr. Emel İSLAMOGLU

Sakarya Üniversitesi

Siyasal Bilgiler Fakültesi

Doç. Dr. Saim OCAK

Marmara Üniversitesi

Hukuk Fakültesi

Doç. Dr. Ercüment ÖZKARACA

Marmara Üniversitesi

Hukuk Fakültesi

Doc. Dr. Gülbiye YENIMAHALLELİ

Ankara Üniversitesi

Sağlık Bilimleri Fakültesi

Doc. Dr. Sinem YILDIRIMALP

Sakarya Üniversitesi

Siyasal Bilgiler Fakültesi 
Prof. Dr. Levent AKIN

Ankara Üniversitesi

Hukuk Fakültesi

Prof. Dr. Yusuf ALPER

Bursa Uludağ Üniversitesi

İktisadi ve İdari Bilimler Fakültesi

Prof. Dr. Özgür ASLAN

İstanbul Üniversitesi

Sağlık Bilimleri Fakültesi

Prof. Dr. Murat ATAN

Ankara Hacı Bayram Veli Üniversitesi

İktisadi ve İdari Bilimler Fakültesi

Prof. Dr. Sibel ATAN

Ankara Haci Bayram Veli Üniversitesi İktisadi ve İdari Bilimler Fakültesi

Prof. Dr. Berrin CEYLAN ATAMAN Altınbaş Üniversitesi

İktisadi, İdari ve Sosyal Bilimler Fakültesi

Prof. Dr. Özlem ATAY

Ankara Üniversitesi

Siyasal Bilgiler Fakültesi

Prof. Dr. Ufuk AYDIN

Anadolu Üniversitesi

Hukuk Fakültesi

Prof. Dr. Hakan BERUMENT

Bilkent Üniversitesi

İktisadi, İdari ve Sosyal Bilimler Fakültesi

Prof. Dr. Özlem ÇAKIR

Dokuz Eylül Üniversitesi

İktisadi ve İdari Bilimler Fakültesi
Prof. Dr. Kamil ORHAN

Pamukkale Üniversitesi

İktisadi ve İdari Bilimler Fakültesi

Prof. Dr. Fatma Füsun ERDEN

Ankara Üniversitesi

Prof. Dr. Şenay GÖKBAYRAK

Ankara Üniversitesi

Siyasal Bilgiler Fakültesi

Prof. Dr. Nuray GÖKÇEK KARACA

Anadolu Üniversitesi

Sağlık Bilimleri Fakültesi

Prof. Dr. Deniz KAĞNICIOĞLU

Anadolu Üniversitesi

Prof. Dr. Handan KUMAS

Pamukkale Üniversitesi

İktisadi ve İdari Bilimler Fakültesi

Prof. Dr. Faruk SAPANCALI

Dokuz Eylül Üniversitesi

İktisadi ve İdari Bilimler Fakültesi

Prof. Dr. Hasan ȘAHIN

Ankara Üniversitesi

Siyasal Bilgiler Fakültesi

Prof. Dr. Suat UĞUR

Çanakkale Onsekiz Mart Üniversitesi

Biga İktisadi ve İdari Bilimler Fakültesi

Prof. Dr. Yücel UYANIK

Ankara Haci Bayram Veli Üniversitesi

İktisadi ve İdari Bilimler Fakültesi
Ziraat Fakültesi

İktisadi ve İdari Bilimler Fakültesi
Prof. Dr. Erinç YELDAN

Bilkent Üniversitesi

İktisadi İdari ve Sosyal Bilimler Fakültesi

Prof. Dr. Handan YOLSAL

İstanbul Üniversitesi

İktisat Fakültesi

Prof. Dr. Sayım YORĞUN

İstanbul Üniversitesi

İktisat Fakültesi

Doc. Dr. Erdem CAM

Ankara Üniversitesi

Siyasal Bilgiler Fakültesi

Doç. Dr. Emel İSLAMOĞLU

Sakarya Üniversitesi

Siyasal Bilgiler Fakültesi

Doç. Dr. Özgür TOPKAYA

Çanakkale Onsekiz Mart Üniversitesi Biga İktisadi ve İdari Bilimler Fakültesi

Doç. Dr. M. Çağlar ÖZDEMIR

Sakarya Üniversitesi

Siyasal Bilgiler Fakültesi

Dr. Öğr. Üyesi Atalay ÇAĞLAR

Pamukkale Üniversitesi

İktisadi ve İdari Bilimler Fakültesi

Dr. Öğr. Üyesi Nagihan DURUSOY ÖZTEPE

Pamukkale Üniversitesi

İktisadi ve İdari Bilimler Fakültesi 


\section{SAYI DEĞERLENDİRME İSTATISTIKLERİ}

EVALUATION STATISTICS FOR THIS ISSUE

Toplam gelen makale başvurusu

Number of received manuscript

Yayına kabul edilen makale sayıs1

Number of accepted manuscript

Hakem süreci devam eden makale sayısı

Under consideration

Red edilen makale sayısı

Rejected after evaluation

20

Ön inceleme aşamasında red edilen makale sayısı

Rejected before evaluation

12

Makale kabul oranı

Accepted manuscript rate

$\% 28$ 
1- Sosyal Güvenlik Dergisi (SGD), yılda iki kez yayınlanan uluslararası, hakemli, bilimsel bir dergidir.

2- Dergiye gönderilen yazılar başka bir yerde yayınlanmamış ya da yayınlanmak üzere gönderilmemiş olmalıdır.

3- Dergide yayınlanmasına karar verilen yazıların, elektronik ortamda tam metin olarak yayınlanmak da dahil olmak üzere, yayın hakları SGK'ya aittir.

4- Yayınlanmak üzere dergiye gönderilen yazılar önce Yayın Kurulunca dergi ilkelerine uygunluk açısından incelenir. Uygunluğu tespit edilen yazılar değerlendirmeleri için yazının ilgili olduğu alanda iki hakeme gönderilir. Hakem raporuna göre; yazarına düzeltme gönderilir, yayınlanır ya da reddedilir.

5- Yayınlanan yazılardaki görüşlerin sorumluluğu yazarlarına aittir. Yayınlanan makaleler atıf yapılmadan kullanılamaz.

6- Dergide yarg1 kararı incelemelerine yer verilebilir.

7- Yazıları yayınlanan yazarlara "Kamu Kurum ve Kuruluşlarınca Ödenecek Telif ve İşleme Ücretleri Hakkında Yönetmelik" çerçevesinde telif ücretleri ödenecektir.

8- SGD Sosyal Güvenlik Dergisi'ne makale gönderenler derginin yayın ilkelerini kabul etmiş sayılırlar.
1- Journal of Social Security is an international, peer reviewed, scientific journal published twice a year.

2- The papers submitted to Journal of Social Security must be unpublished in elsewhere or not synchronically be in the review process of another publication.

3- Social Security Institution and Journal of Social Security own the copyright of the papers published (written and electronic versions).

4- All manuscripts firstly evaluated by Editorial Board and send two independent referees. According to referees' reports, article will be sent to the authors to revise, publish or reject.

5- All the opinions written in articles are under responsilities of the authors. The published contents in the articles cannot be used without being cited.

6- Case review and commentaries are accepted by SGD.

7- Royalty fees will be paid to the authors whose articles published in the Journal of Social Security (SGD) in accordance with the related regulation.

8- Those who send articles to the SGD are considered to have accepted the publication principles of the SGD.

SGD, Sosyal Güvenlik Kurumunun faaliyet alanına, sosyal güvenlik, sosyal politika ve endüstri ilişkileri disiplinine katkısı olabilecek her alanda çalışmalara yer vererek, ülkemizin düşünsel birikimine katkıda bulunmak, toplumda sosyal güvenlik ve sosyal politika bilincini geliştirmek, geleceğe dönük hedef ve beklentileri ortak bir noktada buluşturmak amacıyla yayınlanmaktadır.

SGD, is being published in all areas related social security, social policy and industrial relations to make contribution intellectual life of Turkey, develop the social security and social policy consciousness and bring together the future targets and expectations on the common point of the society. 
İnceleme Makalesi - Review Article

\section{Uluslararası İlke ve Standartlar Bağlamında Yaşlı Hakları ve Sosyal Hizmet Uygulamaları}

\section{Elderly Rights and Social Service Practices in the Context of International Principles and Standards}

\author{
Nuray GÖKÇEK KARACA * \\ ORCID ID: 0000-0003-3493-8446
}

\author{
Sosyal Güvenlik Dergisi / Journal of Social Security \\ Cilt: 9 Sayı: 2 Y11: 2019 /Volume: 9 Issue: 2 Year: 2019 \\ Sayfa Aralığı: 255-274 / Pages: 255-274 \\ DOI: $10.32331 /$ sgd.658637
}

\section{ÖZ}

Tüm dünyada nüfusun yaşlanmakta oluşu, yaşlılığı, yaratacağı ekonomik, sosyal ve sağlık sorunların giderilmesi bağlamında sosyal politikaların odağı haline getirerek uluslararası kuruluşların, devletlerin ve bilimsel çalışmaların gündemine taşımıştır. Böylece özel olarak korunmas1 gereken bir kesim olarak algılanmaya başlanan yaşlıların sahip oldukları haklar Birleşmiş Milletler (BM) başta olmak üzere Dünya Sağlık Örgütü (DSÖ), BM Eğitim Bilim ve Kültür Örgütü, Gıda ve Tarım Örgütü, Uluslararası Çalışma Örgütü (UÇÖ), Avrupa Komisyonu, Avrupa Birliği (AB) gibi birçok uluslararası kuruluşça yapılan düzenlemelerle güvence altına alınmaya çalışılmıştır. Söz konusu uluslararası kuruluşlarca yapılan düzenlemeler bağlamında birçok ülkede olduğu gibi Türkiye'de de yaşlıların korunmasına yönelik yasal düzenlemeler yapılmaktadır. Ancak gerek uluslararası ve gerekse de ulusal düzeydeki doğrudan veya dolaylı bir şekilde yaşlı haklarını güvence altına alan düzenlemelerde bir dağınıklık söz konusudur. Çalışmanın genel amacı, uluslararası ve ulusal mevzuattaki dağınıklığa rağmen yaşlı haklarını bütüncül ve kategorik bir yaklaşımla ortaya koymak ve Türkiye'de söz konusu hakların uygulama boyutunu saptamaktır. Yaşlı haklarının korunması için gerekli yükümlülüklerin daha belirgin hale getirilerek kamusal farkındalık ve bilinç oluşturmak ise çalışmanın sonuç hedefidir. Çalışmada niteliksel veri toplama tekniği olarak literatür taramasından yararlanılmıştır.

Anahtar Sözcükler: Yaşl1, yaşlılık, yaşlanma, yaşlı mevzuatı, yaşı hakları

\section{ABSTRACT}

The aging of the population in the whole the world has brought the elderly to the agenda of international organizations, states and scientific studies by making them the focus of social policies in the context of reducing economic, social and health problems. In this way, the rights of the elderly, who are perceived as a special protection group are tried to be guaranteed in regulations made by international organizations such as the United Nations (UN), the World Health Organization (WHO), the United Nations Educational Science and Culture Organization, the Food and Agriculture Organization, the International Labor Organization (ICC), the European Commission, the European Union (EU). As mentioned in many countries in the context of arrangements made by international organizations in Turkey, it is made legal arrangements for the protection of the elderly. However, there is a disorganization in regulations that guarantee the rights of the elderly, either directly or indirectly, both at the international and national levels. The general purpose of the study is to provide a holistic and categorical approach to the rights of the elderly despite the disorganization of international and national legislation and to determine the application scope of those rights in Turkey. The objective of the study is to create public awareness and awareness by making the obligations necessary for the protection of the rights of the elderly more specific. In the study, literature search was used as qualitative data collection technique.

Keywords: Elderly, aging, aging, elderly legislation, elderly rights

Önerilen atıf şekli: Gökçek Karaca, N. (2019). Uluslararası İlke ve Standartlar Bağlamında Yaşlı Hakları ve Sosyal Hizmet Uygulamaları. Sosyal Güvenlik Dergisi (Journal of Social Security). 9(2). 255-274. 


\section{GİRIŞ}

Temel hak ve özgürlükler ya da insan hakları, tüm insanlığa özgü, doğuştan sahip olunan kişiliğe bağlı vazgeçilmez ve devredilmez haklardır. Her insan, insan olma bakımından eşit değere sahiptir. İnsanca yaşama hakkına sahip olmak açısından insanlar arasında ayrım yapılamaz. Ancak yaşamlarını başkalarının desteği olmaksızın sürdürme konusunda zorlanan yaşlıların, yaşam kalitesi ve yaşamdan beklentilerinin sağlıklı bireylerden farklı olduğu gerçeğinden hareketle, diğer insanların sahip oldukları eğitim hakkı, sosyal güvenlik hakkı, sağlık hakkı vb. haklara ilaveten, özel durumlarına özgü bakım hakkı, rehabilitasyon hakkı, sosyal yardım ve hizmetlerden yararlanma hakkı gibi bazı özel haklara sahip olması sosyal uyum açısından bir zorunluluktur. Bu bağlamda, yaşlı bireylerin saygınlıklarını koruyarak bağımsız yaşayabilmeleri, kendilerini gerçekleştirebilmeleri ve yaşamın her alanına eşit katılımlarının sağlanması konusunda hemen hemen tüm çağdaş ülkelerin önemli yükümlülükler üstlendiği, yaşlı haklarının yasal düzenlemelerle güvence altına alındığı, çoğu zaman engelli bireyler için öngörülen hakların yaşlı bireyler için de geçerli kılındığı görülmektedir.

Uluslararası ve ulusal düzeyde yapılan yaşlı haklarını güvence altına alan düzenlemeler dağınık halde bulunmaktadır. Çalışmanın amacı, yaşlılara yönelik dağınık halde bulunan mevzuatın bir araya getirilerek konular açısından bir arada ve topluca değerlendirilmesi, yaşlı haklarının korunması için gerekli yükümlülüklerin daha belirgin hale getirilerek kamusal farkındalık ve bilinç oluşturulmasıdır. Değinilen amaç doğrultusunda yapılan çalışmada, öncelikle yaşlılık kavramı ve yaşlı nüfusun önemine vurgu yapmak adına Dünyada ve Türkiye'de yaşlı nüfus hakkında bilgi verilecek, ardından uluslararası ilke ve standartlar çerçevesinde yaşlı hakları kategorize edilerek, Türkiye'de yaşlı hakları bağlamında sosyal hizmet uygulamaları inceleme konusu yapılacaktır.

\section{I- YAŞLILIK KAVRAMI VE YAŞLI NÜFUSUN ÖNEMI}

Yaşl1lık, önüne geçilmesi mümkün olmayan biyolojik, kronolojik, sosyal yönleri ve sorunları olan bir süreçtir. Yaşlılık dönemi, yaşlanmaya bağlı olarak insan vücudunda meydana gelen deformasyon ve gerileme nedeniyle fiziksel yeteneklerin azaldığı, pek çok kronik hastalığın yaşandığı, bağımlılık ve kaza riskinin arttığı, bireylerin statü kaybettiği ve günlük işlevlerini yerine getirmede desteğe ihtiyaç duyduğu bir dönemdir (Emiroğlu, 1995: 35-43; Karahan ve Güven, 2002: 156; Karataş, 2011: 30; Özgür ve Sabbağ, 2014: 23-75). Yaşlılık tarihsel süreçlere göre çeşitlilik gösteren ve kültürden kültüre değişen bir olgu olduğu için yaşlılık kavramı da çağa, bölgeye ve toplumsal gelişmişliğe göre farklılaştığı gibi bireyin sağlik, sosyal ve psikolojik durumuna göre de değişebilmektedir (Tufan, 2002: 87: Arpac1, 2005: 15; Çağlar, 2017: 21-28; Evren, 2018: 138). Dünya Sağlık Örgütü (DSÖ) tarafından söz konusu değişmeler üzerine temellendirilen yaşlılık kavramı, "bireyin kontrolünün dışında ortaya çıkan ve çevresel faktörlere uyum sağlayabilme yeteneğinin azaldı̆̆ biyolojik bir dönem” olarak tanımlanmaktadır (World Health Organization, 2017). DSÖ, yeni yaş dilimi listesine göre 80 yaş ve üzerini yaşlı olarak kabul etmekte, daha önce genç yaşlılık olarak ifade ettiği 65-75 yaş arası dönemi ile 75-80 arası dönemi, 65-79 yaş arası dönem olarak birleştirip orta yaş kategorisinde değerlendirmektedir. Dolayısıyla DSÖ’nün yeni yaş dilimi listesine göre 80-99 yaş aralığında bulunanlar yaşlı olarak kabul edilmektedir. DSÖ'nün yeni yaklaşımına göre çalışma hayatından emekliye ayrılmayı takip eden dönem ile fonksiyonel kayıpların görülmeye başlandığı dönemler itibariyle bireyler yaşlı kabul edilmemekte, birey doğrudan özel bakım, özel ev ve yardımcıya ihtiyaç duymaya başladığı dönemler itibariyle yaşlı kabul edilmektedir (Görpelioğlu, 2009: 22; Er, 2009: 135). Daha önceki sınıflama gibi yeni sınıflama da herkes için geçerli olmayabilir. 
Nitekim 80 yaşında çok dinç birisiyle karşılaşabileceğimiz gibi 60 yaşında özel bakıma ihtiyaç duyan kişilere de rastlayabiliriz (Yılmazer, 2013: 2).

Türkiye'de yasal düzenlemeler incelendiğinde ise yaşlılık statüsüne girmek için kabul edilen eşik değerin (65 yaş), DSÖ’nün yeni kabul ettiği yaş aralıklarının çok gerisinde olduğu görülmektedir (Evren, 2018: 139).

Birleşmiş Milletler'in (BM) tanımına göre, bir ülkedeki yaşlı nüfusun toplam nüfus içindeki oranının $\% 8$ ile $\% 10$ arasında olması o ülke nüfusunun "yaşlı", \%10'un üzerinde olması ise "çok yaşlı" olduğu anlamına gelmektedir (Karacan, 2017: 638). 2016 yılı verilerine göre dünya nüfusunun \%8,7'sini yaşlı nüfus oluşturmaktadır. Türkiye'de ise yaşlı nüfus 2013 yılında 5.891.694 iken \%21,5 artarak 2018 yılında 7.163.354 kişi oldu. Yaşlı nüfusun toplam nüfus içindeki oranı ise 2013 yılında \%7,7 iken, 2018 yılında \%8.7'ye yükseldi. 2017 verilerine göre \%44'ünü erkeklerin, \%56'sını kadınların oluşturduğu 6.895.385 kişiden oluşan yaşlı nüfusun \%61.6'sı 65-74 yaş grubunda, \%29.7'si 75-84 yaş grubunda ve \%8.6'sı ise 85 ve daha yukarı yaş grubunda yer almaktadır. Verilere göre Türkiye kısa bir süre sonra "çok yaşlı" toplum kategorisine girecektir (TÜIK, 2017). Söz konusu demografik değişime bağlı olarak karşılaşılabilecek sorunları minimize etmek için yaşlıların korunmasına yönelik sosyal, ekonomik, sağlık politika ve uygulamaların hayata geçirilmesi kaçınılmazdır.

\section{II- YAŞLILARA YÖNELİK ULUSLARARASI İLKE VE STANDARTLAR}

Özel olarak korunması gereken diğer gruplarla karşılaştıııldığında, yaşlıların korunmasına yönelik uluslararası düzeyde yapılan çalışmaların göreli olarak çok daha yeni ve daha sınırlı düzeyde olduğu görülmektedir. Uluslararası literatür incelendiğinde, yaşlıların korunmasının Dünya genelinde 20. yüzyılda toplumun yaşlanması sorununa bağlı olarak gündeme geldiği ve BM, DSÖ, BM Eğitim Bilim ve Kültür Örgütü, Gıda ve Tarım Örgütü, Uluslararası Çalışma Örgütü (UÇÖ), Avrupa Komisyonu, Avrupa Birliği (AB) gibi kuruluşların özel olarak korunması gereken diğer gruplara oranla daha sınırlı düzeyde de olsa, doğrudan veya dolaylı bir şekilde yaşlıların korunması ile ilgili olarak çeşitli belge, ilke ve programlar oluşturdukları görülmektedir. Bu bağlamda ilk girişimin, BM tarafından 1982 yılında Viyana'da yapılan BM Dünya Yaşlılık Konferansı ile başlatıldığ 1 görülmektedir. Öncülüğünü BM'nin yaptığı yaşlıların korunmasına yönelik ilk uluslararası çalışmayı, Avrupa Konseyi, AB ve ÜÇO tarafından yapılan çalışmalar takip etmiştir.

\section{A- BM Tarafından Yapılan Düzenlemeler ve Çalışmalar}

BM tarafından özel olarak korunması gereken gruplardan ayrımcılık mağdurları, kadınlar, çocuklar ve engellilere özgü birçok sözleşme kabul edildiği halde yaşlılara yönelik bir sözleşme henüz kabul edilmiş değildir. BM'nin yaşlılarla ilgili düzenlemelerini genellikle diğer gruplara özgü düzenlemelerde dolaylı bir şekilde göndermelerde bulunulan yaşlılarla ilgili hükümler oluşturmaktadır. Söz konusu düzenleme ve çalışmalar, kabul ediliş tarihlerine göre 1948 tarihli İnsan Hakları Evrensel Bildirgesi, 1966 tarihli Uluslararas1 Ekonomik, Sosyal ve Kültürel Haklar Sözleşmesi, 1969 tarihli Toplumsal Gelişme ve Kalkınma Bildirgesi, 1982 tarihli Dünya Yaşlılık Konferansı, 1991 tarihli BM Yaşlı İlkeleri, 1995 tarihli Kopenhag Toplumsal Kalkınma Bildirgesi, 1999 tarihli DSÖ Uluslararası Yaşlılar Yılı ve Yaşlılara Yönelik Eylem Planı, 2000 tarihli BM Bin Yı1 Bildirgesi ve 2002 tarihli BM Madrid Dünya Yaşlanma Konferansı şeklinde sıralanarak açıklanabilir: 
Insan Hakları Evrensel Bildirgesi, bakım hakkını ve sosyal güvenlik hakkının düzenlendiği 25. maddesinde yaşlılık sosyal güvenliği gerektiren geçim sıkıntısı durumu yaratabilecek bir koşul olarak sayılmıştır.

Uluslararası Ekonomik, Sosyal ve Kültürel Haklar Sözleşmesi'nin ailenin, anneliğin, çocukların ve gençlerin korunmasına yönelik 10. maddesinde yaşlılarla ilgili bir düzenleme yer almamakla birlikte ailenin korunması bağlamında dolaylı bir şekilde yaşlı haklarına göndermeler söz konusudur (Mertoğlu, 2013: 12).

1969'da BM, ömür uzaması ve nüfus artışını gündeme getirdiği Toplumsal Gelişme ve Kalkınma Bildirgesi'nin 11. maddesinde yaygın toplumsal güvenlik sistemleri ve toplumsal yardım hizmetlerinin sağlanması; hastalık, engel ve yaşlılık nedeniyle geçici ya da sürekli olarak geçimini sağlayamayan herkese kendileri, aileleri ve bağımlı kimseleri için uygun bir yaşam standardı sağlamak üzere toplumsal güvenlik ve sigorta sistemlerinin kurulması ve geliştirilmesi; çocukların, yaşlıların ve engellilerin haklarının korunması ve refahının sağlanması; bedensel ve zihinsel engellilerin korunması gerektiğini hüküm altına almıştır.

Dünya genelinde 20. yüzyılda dikkati çekmeye başlayan toplum yaşlanması uluslararası düzeyde ilk kez Viyana'da 1982 yılında yapılan BM Dünya Yaşlılık Konferansı'nda gündeme gelmiştir. Söz konusu Konferansta yapılan uyarılara rağmen hükümetlerin yaşlılığa destek hizmetlerinde çok geriden gelmekte oldukları tespit edilmiş ve İnsan Hakları Evrensel Bildirgesinin ve Uluslararası Ekonomik, Sosyal ve Kültürel Haklar Sözleşmesi'nin yaşlılar için uygulanmasını sağlamak üzere "Hükümetlere Yol Gösterici 62 Karar" alınarak yayınlanmıştır. Bunları takip etmek için her yıl "1 Ekim”in "Dünya Yaşlılar Günü" olması ilan edilmiş ve her ülkeden 4 yılda bir "Ülke Yaşlılık Raporu" yayını istenmeye başlanmıştır (Gökçek Karaca, 2016: 42; Mertoğlu, 2013: 12).

Uluslararası Yaşlanma Eylem Planı temelinde hazırlanmış olan BM'nin 16 Aralık 1991 tarihli 74. toplantısında alınan kararla Yaşı Bireylere İlişskin BM İlkeleri kabul edilmiştir. BM'nin ülkeleri mümkün olduğunca ulusal programlarına uyarlamaların önerdiği yaşlı bireylere ilişkin ilkeleri; bağımsız yaşam, katılım, bakım, kendini gerçekleştirme ve itibardır. Söz konusu ilkeler bağlamında her yaşlı bağımsız yaşama, sosyal ve ekonomik yaşama katılım, bakım, kendini gerçekleştirme ve itibar görme hakkına sahiptir.

6-12 Mart 1995 tarihleri arasında Kopenhag'da yapılan Dünya Toplumsal Kalkınma Zirvesi sonucunda 100 maddelik bir eylem programı hazırlanmıştır (BM Enformasyon Merkezi, 2007). Hazırlanan eylem programında engelliler, yerliler, sığınmacılar ve yurtlarından ayrılmış insanlar gibi yaşlıların da özellikle yoksulluk karşısında korunmasız durumda olduğuna vurgu yapılmış ve diğer risk grupları ile birlikte yaşlıların korunmasına yönelik aşağıda belirtilen birçok düzenlemeye yer verilmiştir.

- Yoksullukla mücadeleye dönük önlemlerin en kısa sürede yaşama geçirilmesi gerektiğinin vurgulandığ 125 . maddede yaşlılık dönemlerinde herkese yeterli ekonomik ve toplumsal korumanın sağlanmasına yönelik politikalar belirlenmesi gerektiği hüküm altına alınmıştır.

- Kentlerdeki yoksulluk sorununun nasıl ele alınması gerektiğini açıklayan 34/h maddesinde yaşlıların bütün toplumsal hizmetlerden yararlanmalarının sağlanması gerektiği belirtilmiştir.

- "Daha Etkin Toplumsal Korunma ve Daha Az Korunmasızlık" başlığını taşıyan 38. maddede diğer risk grupları ile birlikte toplumsal koruma sistemlerinin yaşlılık halinden dolayı geçinemeyecek durumda olanları da kapsaması gerektiği belirtilmiştir. Ayrıca aynı maddede yaşlı kadınlara destek verilmesi gerektiği de ifade edilmektedir. 
- Yaşlıların korunması için özel çaba harcanması gerektiğini vurgulayan 40. maddede ayrıca yaşlıların korunması için alınması gereken önlemlerin neler olması gerektiği belirtilmiştir.

- Ailenin destek sağlayan sistemlerinin güçlendirilmesi

- Yaşlıların özellikle yeterli aile desteği alamayanların, kırsal alanlarda yaşayan, çalışan, silahlı çatışmalardan ve doğal ya da insan eseri felaketlerden etkilenen yaşlıların, sömürülen, bedensel ya da psikolojik olarak ihmal edilen ya da kötüye kullanılan yaşlıların durumlarının iyileştirilmesi

- Yaşliların, toplumsal hizmetlerden ve toplumsal güvenlik ağlarından yararlandırılarak temel insani gereksinimlerinin karşılanması; muhtaç durumda olanlara yardım edilmesi ve yaşlıların kötüye kullanılma ve şiddet karşısında koruma altına alınması ve taşınması gereken bir ağırlık olarak değil, yararlanılacak bir kaynak olarak davranılarak korunmaya alınmaları

- Çocukların sorumluluğunu üstlenmesi beklenen büyükanne ya da büyükbabalara yardım etmek, özellikle, AIDS ya da cüzam gibi hastalıklara yakalanmış ve/veya bakmaları istenen kişilere bakamayacak durumda olan yaşlılara yardım sağlamak

- Gençlerin yaşlılıklarında kullanmak üzere tasarruf yapmalarını olanaklı kılacak bir mali ortamin yaratılması

- Emekli işçilerin yoksulluğa düşmemeleri için, ülkelerinin kalkınmasına yaptıkları katkıları dikkate alınarak, gereken önlemlerin alınması ve uygun mekanizmaların oluşturulması

- Politika ve program belirlemelerinde ve karar oluşturma ortamlarında, her düzeyde, her kuşaktan katılımın teşviki ve desteklenmesi

- $\quad$ Eylem programının 46. maddesinde yaşlılara bakmanın toplumsal önemine vurgu yapılmıştır.

- $\quad$ Eylem programının 53. maddesinde kadınların yeterli yaşlılık bakımı vb. yöntemlerle, emek gücüne katılımlarının ve yeniden katılımlarının kolaylaştııılması gerektiği belirtilmiştir.

- Eylem programının 58. maddesinde uzun dönemli işsizliğin belirgin nedenlerinin diğer risk grupları gibi yaşlı işçilerin koşulları üzerindeki etkilerinin incelenmesi ve özel durumlara ve gereksinimlere çözüm getirebilecek istihdam ve diğer destekleyici politikaların tasarımlanması gerektiği belirtilmiştir.

- $\quad$ Eylem programının 65. maddesinde başkalarının bakımına muhtaç yaşlılara yardım etmek ya da eğitim yardımına ve toplumsal desteğe gereksinmesi olan ailelere destek verilmesi gerektiği belirtilmiştir.

- Eylem programının 69. maddesinde yaşlilara yönelik değişik biçimlerdeki şiddete bireylerin, ailelerin ve toplulukların güvenliklerini tehdit eden bir olgu olarak son verilmesi ve çözüme kavuşturulması gerektiğine vurgu yapılmıştır.

- $\quad$ Eylem programının 74. maddesinde yaşlılara eğitim olanağı sağlamak için özel önlemler alınması gerektiği ve temel eğitimin yaygınlaştırılmasına vurgu yapılmıştır.

- Eylem programının 75. maddesinde ise yaşlıların topluma katkılarının en fazlaya çıkarılabilmesi ve içinde yaşadıkları topluluğa mümkün olan en yüksek düzeyde 
katılımlarının sağlanabilmesi için Yaşlılara İlişkin BM İlkeleri çerçevesinde ve 2001 yılında yaşlanma konusunda bütün dünya için belirlenmiş olan hedefleri dikkate alarak, Uluslararası Yaşlılık Eylem Programı'nın hükümlerinin uygulanmasını gözden geçirmek ya da bu konuda stratejiler geliştirmek gerektiği hüküm altına alınmıştır.

Toplum yaşlanmasının giderek artan önemi ile birlikte DSÖ tarafindan 1999 yılı "Uluslararası Yaşlılar Yılı" olarak ilan edilmiş ve "Yaşlılara Yönelik Eylem Planı" hazırlanarak, üretken ve aktif yaşlılık sürecinin önemi üzerinde durulmuştur.

6-8 Eylül 2000 tarihleri arasında Birleşmiş Milletler'in New York'taki Genel Merkezinde, aralarında Türkiye'nin de bulunduğu 189 ülkenin Devlet ve Hükümet Başkanlarının katılımıyla, "yeni bir binyılın başlangıcında" yapılan liderler zirvesinde, günümüzün en güçlü ve öncelikli küresel taahhüt belgelerinden biri olarak kabul edilen BM Binyıl Bildirgesi'nde, "tüm dünyada adil ve kalıcı bir barış sağlanması" kararlılığının dile getirilmesinin ardından, dünya ölçeğinde üstesinden gelinmesi gereken en temel sorunun, "küreselleşmenin tüm insanlık için olumlu bir güce dönüştürülmesi" olduğu vurgulanmaktadır. Küreselleşmenin sağladığı nimetlerin günümüzde çok dengesiz bir biçimde paylaşıldığı ve külfetinin de yine dengesiz bir biçimde dağıldığı saptaması yapıldıktan sonra "küreselleşme, ancak tüm çeşitliliği ile insanlığı kapsayan ortak bir gelecek kurmaya yönelik geniş kapsamlı ve sürekli çabalarla herkesi kucaklayan ve adil bir sürece dönüştürebilir" denmektedir. Bildirgede 21.yüzyılın uluslararası ilişkileri açısından zorunlu görülen temel ilkelerin "özgürlük, eşitlik, dayanışma, hoşgörü, doğaya saygı ve ortak sorumluluk" olduğu belirtilerek, değinilen ilkelerin yaşama geçirilmesine yönelik özgürlük, demokrasi ve insan hakları konularındaki taahhütlerin yanı sıra, bir dönüm noktası olması öngörülen 2015 yılına kadar gerçekleştirilmek üzere, kalkınma ve yoksullukla mücadeleye dönük aşırı yoksulluğun ve açlığın azaltılması, evrensel temel eğitimin sağlanması, cinsiyetler arası eşitliğin sağlanması ve kadınların yapabilirliklerinin arttırılması/desteklenmesi, bebek ölümlerinin azaltılması, ana-çocuk sağlığının iyileştirilmesi, HIV/AIDS, sıtma ve diğer hastalıklarla mücadele edilmesi, çevresel sürdürülebilirliğin sağlanması ve kalkınma için küresel bir ortaklık geliştirilmesi şeklinde sekiz hedef (Binyıl Kalkınma Hedefleri) belirlenmiştir (BM, 2019). Saptanan hedefler doğrultusunda yaşlıların korunmasına yönelik hükümlere yer verilmesi gerektiği halde BM Bin Y1l Bildirgesi'nde "VI. Güçsüz Kesimlerin Korunması" başlığg altında, yaşlılara yer verilmemiştir (Mertoğlu, 2013:12).

Viyana'da yapılan ilk toplantıdan 20 yıl sonra, 2002 yılında, Dünya Yaşlanma Konferansı Madrid'te yapılmış ve 2002 Eylem Planı yürürlüğe konulmuştur. Amacı, her yerde insanların güven ve saygın şekilde yaşlanmalarını ve toplumlarında bütün haklara sahip birer vatandaş olarak yaşamaya devam etmelerini güvence altına almaktır. Söz konusu amaç doğrultusunda yaşlılar için koruyucu ve rehabilite edici hizmetler dâhil olmak üzere, sağlık hizmetleri, destek ve sosyal koruma sağlanması için gerekli olanların yapılması gerektiğine vurgu yapmak olan söz konusu eylem planı içinde yer alan amaç, hedef ve taahhütler şunlardır (Dural ve Con, 2013: 485-490; Yaşlı Bakıcısı, 2019):

- Yaşlıların insan haklarının ve temel özgürlüklerinin tam olarak tanınması ve gerçekleştirilmesi,

- Yaşlıların ekonomik, politik ve sosyal yaşama tam ve etkili olarak katılması amacıyla güçlendirilmesi,

- Yaşlılara yaşam boyu öğrenme ve toplum içinde yer alma olanaklarına erişim gibi firsatların yaşamın ileri yıllarında da sağlanarak yaşam boyunca bireysel gelişme, kişisel tatmin ve iyi olma durumlarının sürdürülmesi, 
- $\quad$ Bütün ekonomik, sosyal, kültürel hakların yanında vatandaşlık ve siyasi haklara da sahip olmalarının sağlanması ve yaşlılara karşı her türlü şiddet ve ayrımcılığın ortadan kaldırılması,

- Cinsiyete dayalı ayrımcılığın ortadan kaldırılması yoluyla yaşlılarda cinsiyet eşitliğinin sağlanması,

- $\quad$ Sosyal kalkınma için ailenin önemi, kuşaklar arası bağlılık, dayanışma ve karşılıklı ilişkilerin öneminin kavranması,

- Yaşlılar için, koruyucu ve rehabilite edici hizmetler dâhil olmak üzere, sağlık hizmetleri, destek ve sosyal koruma sağlanması,

- Uluslararası Eylem Planı’nın uygulamaya dönüştürülmesi için yaşlılar ile hükümet, sivil toplum ve özel sektörün bütün düzeyleri arasında işbirliğinin kolaylaştırılması,

- $\quad$ Özellikle gelişmekte olan ülkelerde, birçok diğer konunun yanı sıra yaşlanmanın bireysel, sosyal ve sağlık yönleri üzerinde odaklanmak amacıyla bilimsel araştırmalar yapılarak, bilgi ve becerilerin artırılması ve teknolojiden yararlanılması,

- Yaşlanmakta olan bireylerin durumlarının ve farklı koşullarının tanınması ve onları etkileyen konularda seslerini duyurmalarının sağlanması için çeşitli yolların araştırılması gerektiğinin kabul edilmesi.

\section{B- Avrupa Konseyi Tarafından Yapılan Düzenlemeler ve Çalışmalar}

Avrupa Konseyi'nin doğrudan veya dolaylı bir şekilde yaşlıların korunmasına yönelik birçok düzenlemesi olmakla birlikte konumuz açısından iki temel belgesi ayrı bir öneme sahiptir. Söz konusu belgelerden biri klasik kişisel ve siyasal hakları güvence altına alan "İnsan Hakları ve Temel Özgürlüklerin Korunmasına İlişkin Sözleşme” iken, bir diğeri ise sosyal ve ekonomik hakları güvence altına alan "Avrupa Sosyal Şartı”dır.

“Avrupa İnsan Hakları Sözleşmesi” olarak da adlandırılan "İnsan Hakları ve Temel Özgürlüklerin Korunmasına İlişkin Sözleşme”, klasik kişisel ve siyasal hakları güvence altına alır. Avrupa Konseyi kurulduğundan bugüne insan haklarının korunması ve geliştirilmesine önem ve öncelik vermiş ve kuruluşundan çok kısa bir süre içinde Avrupa İnsan Hakları Sözleşmesi'ni hazırlamıştır. Söz konusu sözleşmeyle BM İnsan Hakları Evrensel Bildirgesi'ndeki hakların her yerde ve etkin olarak korunması, geliştirilmesi ve güvenceye kavuşturulması amaçlanmıştır. Avrupa İnsan Hakları Sözleşmesi'nde doğrudan yaşlıların korunmasına yönelik düzenlemeler yoktur. Böyle olmakla birlikte genel nitelikteki bazı düzenlemelerden yaşlılar da yararlanabilmektedir. Nitekim Avrupa İnsan Hakları Sözleşmesi'nde yaş bakımından ayrımcılık yasağı olmamasına rağmen 14. maddesinde yer alan ayrımcılık yasağı, yaşa dayalı ayrımcılık yapılmasını da kapsadığından değinilen düzenlemeden yaşlılar da yararlanabilmektedir.

Avrupa Sosyal Şartı, ekonomik ve sosyal hakları güvence altına alır. Sağlığın korunması hakk1, sosyal güvenlik hakk1, sosyal ve tıbbi yardım hakkı ve sosyal refah hizmetlerinden yararlanma hakkı bakım hizmetlerinden yararlanma hakkı ekonomik ve sosyal haklar kapsamında güvence altına alınan haklar arasındadır. Sosyal ve ekonomik hakların korunması alanında Avrupa İnsan Hakları Sözleşmesini tamamlayıcı bir belge olan Avrupa Sosyal Şartı, "istihdam koşulları" ve "sosyal bağlılık" şeklinde iki temel kategoriye ayrılabilecek nitelikte bir dizi hakkı güvence altına almaktadır. Hiç kuşkusuz söz konusu haklardan sağlığın korunması hakkı, sosyal güvenlik hakkı, sosyal ve tıbbi yardım hakkı ve 
sosyal refah hizmetlerinden yararlanma hakkı bakım hizmetlerinden yararlanmayı da kapsamına alan temel haklardır.

Avrupa Sosyal Şartı, 1996 yılında hazırlanmasından 35 yıl sonra, uygulamadan kazanılan deneyimlerden de yararlanılarak, etkinliğini artırmak ve özellikle izleme mekanizmasının daha iyi işlemesini sağlamak amacıyla yeniden gözden geçirilmiş ve yeni bir takım hakları da güvence altına alacak bir şekilde geliştirilmiştir. Gözden geçirilmiş Şartın 23. maddesinde akit taraflara yaşlıların sosyal korunma hakkını etkili bir şekilde kullanmasını sağlamak amacıyla doğrudan harekete geçme veya kamu ve özel sektörle işbirliği yapma yükümlülüğü getirilmiştir. Söz konusu maddede yaşlıların mümkün olduğunca uzun bir süre iyi bir yaşam sürmeleri ve sosyal ve kültürel hayatta aktif bir rol oynamalarına imkân verecek uygunlukta kaynak sağlanması, yararlanabilecekleri hizmet ve kolaylıklar hakkında bilgilendirilmeleri, kendi hayat tarzlarını serbestçe seçmeleri ve bildikleri çevrede sağlık durumlarına uygun konut sağlanması, evlerini sağlık koşullarına uygun hale getirmeleri için destek verilmesi ve durumlarına uygun sağlı hizmetleri sunulması, kurumlarda yaşayan yaşlılara uygun destekler verilmesi ve onların özel hayatlarına ve kuruma ilişkin karar alma süreçlerine katılma olanağı tanınması gerektiği hüküm altına alınmıştır (Evren, 2018: 146).

\section{C- AB Tarafından Yapılan Düzenlemeler ve Çalışmalar}

1997 yılına kadar Avrupa Birliği hukukunda cinsiyet ve vatandaşlık temelli ayrımcılık yasağı söz konusu iken, 1997 yılında Amsterdam Antlaşması ile Avrupa Toplulukları Antlaşması'na 13. madde ile yeni ayrımcılık temelleri eklenmiş oldu. 13. madde ile Avrupa Birliği Konseyi’ne belirtilen temellerde ayrımcılıkla mücadele için önlemler alma yetkisi getirildi. AB üyesi ülkeler için hukuken bağlayıcılığı tartışmasız olan Avrupa Toplulukları Anlaşması'nın 13. maddesine göre Konseyin, Avrupa Parlamentosu'nun muvafakatini aldıktan sonra, özel yasama usulü uyarınca hareket eden, oybirliğiyle, cinsiyet, rrk ve etnik köken, dini inan veya kanaat, engellilik, yaş veya cinsel tercih temelinde yapılan ayrımcılıkla mücadele amacıyla gerekli tedbirleri alacağı; AB Anayasasının II-85. maddesinde ise, Birliğin yaşlı haklarını ve yaşlıların onurlu, bağımsız bir hayat sürme ve sosyal ve kültürel hayata katılma haklarına saygı duyacağı belirtilmektedir (Evren, 2018: 146).

Hukuki bağlayıcılığı tartışmalı olmakla birlikte AB açısından ayrımcılık yasağı kapsamında belirtilebilecek ilk düzenleme olan 2000 yılında kabul edilen AB Temel Haklar Şartı'nın 21. maddesinde ise yaş temelinde ayrımcılık yapılması yasaklanmış, 25. maddesinde ise Birliğin yaşlıların saygın ve bağımsız bir yaşam sürdürme ve sosyal ve kültürel hayata katılma hakkını tanıyıp saygı duyacağı belirtilmiştir (Evren, 2018: 147).

Avrupa çerçevesinde, refah devletleri ve yaşlılar arasındaki ilişki sosyal haklar çerçevesinde düzenlenmiştir. Dolayısıyla devlet ve yaşlılar arasındaki ilişki sosyal güvenlik hakk1, sosyal ve tıbbi yardım hakk1, sosyal refah hizmetlerinden yararlanma hakk1, yaşlıların toplumda yaşamda bağımsız olma, sosyal bütünleşme ve katılma hakkı şeklinde dört temel hakka dayanmaktadır.

\section{D- UÇÖ Tarafından Yapılan Düzenlemeler ve Çalıșmalar}

UÇÖ, 1919'da imzalanan Versay Barış Anlaşması ile Birinci Dünya Savaşından sonra giderek büyüyen sorunlara yönelik sosyal reform niteliğinde çözümler bulmak ve reformların uluslararası düzeyde uygulanmasını sağlamak amacıyla kurulmuş, çalışma yaşamını düzenlemeye dönük faaliyetlerde bulunan bir kuruluştur. UÇÖ’nün faaliyetleri arasında engellilerin ve yaşlılar ile birlikte diğer dezavantajlı kesimlerin çalışma yaşamında korunmasına dönük düzenlemeler ihtiva eden sözleşmeleri ve tavsiye kararları önemli bir 
yer tutmaktadır. Hiç kuşkusuz söz konusu düzenlemelerden ilki, çalışma hayatından ayrılmaya yol açan, daha sonrasında bireyin sürekli gelir kaybına uğramasına neden olan ve bireyi ekonomik olarak sarsan bir sosyal risk olarak bireyleri yaşlanma riskine karş1 güvence altına alan 1933 tarih ve 35 sayılı Yaşlılık Sigortası (Sanayi) Sözleşmesi ve 36 sayılı Yaşlılık Sigortası (Tarım) Sözleşmesidir. Benzer nitelikte yaşlanma riskine karşı yaşlının bizzat kendisini ve hak sahiplerini korumaya yönelik hükümler içeren bir diğer ILO Sözleşmesi ise 1967 tarih ve 128 sayılı Malullük, Yaşlılık ve Ölüm Yardımlarına İlişkin Sözleşmedir. Yine yaşlılığı; hastalık, analık, malullük ve ölüm ile birlikte güvence altına alınması gereken beş temel fizyolojik riskten biri olarak kabul eden bir diğer ILO düzenlemesi ise 1952 tarih ve 102 sayılı Sosyal Güvenliğin Asgari Normları Sözleşmesidir.

ILO’nun yaşlıları çalışma yaşamında ayrımcılığa karşı korumaya dönük düzenlemeleri de mevcuttur. Bu bağlamda dikkat çekici ilk düzenleme, 1958 tarih ve 111 sayılı Ayrımcılık (İstihdam ve Meslekler) Sözleşmesidir. Sözleşmede ayrımcılığın yasaklandığı alanlar arasında yaştan söz edilmemekle birlikte, aynı belgede yer alan mad.1/1-b uyarınca bazı ülkeler yaşı da ayrımcılık yapılamayacak alanlar arasına almıştır. Ayrıca söz konusu Sözleşmenin 5. maddesinde de çalışanların yaşla ilgili gereksinimlerinin karşılanmasında özel önlemlerin alınmasının mümkün olduğu ifade edilmektedir. Nitekim ILO 1980 tarih ve 162 sayılı Yaşlı Çalışanlar Tavsiye Kararı'nda yaşlı çalışanların istihdam sorunlarının; tam istihdamı gözeten genel ve iyi dengelenmiş bir çerçevede ele alınması, işletme düzeyinde genel ve dengeli bir sosyal politika gözetilmesi, tüm nüfus gruplarına gerekli dikkatin gösterilmesi ve böylece istihdam sorunlarının bir gruptan diğerine aktarılmasına meydan verilmemesi gerektiğini belirtmiştir (UÇÖ, 2019).

\section{III- YAŞLILARA YÖNELİK ULUSAL DÜZENLEMELER VE ÇALIŞMALAR}

Uluslararası ilke ve standartlar çerçevesinde oluşan yaşlı hak, yetki ve korumalarının Türk mevzuatında dağınık halde de olsa, büyük oranda yaşlılara tanındığı görülmektedir. Söz konusu dağınıklığın giderilmesi açısından ülkemizde yaşlılara yönelik hizmet ve uygulamaların ulusal hukuki dayanaklarını kanunlar ya da normlar hiyerarşisine göre incelemek mümkündür.

\section{A- T.C. Anayasası}

18.10.1982 tarih ve 2709 sayılı T.C. Anayasası (R.G., T. 09.11.1982, S. 17863 (Mükerrer)'nın doğrudan veya dolaylı bir şekilde yaşlı haklarını güvence altına alan hükümlerinden ilki, refah devleti anlayışını benimsemiş çağdaş demokrasilerde olduğu gibi, T.C.'nin toplumun huzuru, milli dayanışma ve adalet anlayışı içinde, insan haklarına saygıll, Atatürk milliyetçiliğine bağlı, başlangıçta belirtilen temel ilkelere dayanan, demokratik, laik ve sosyal bir hukuk devleti olduğunu belirten 2. maddesidir. Yine Anayasa'nın herkesin dil, ırk, renk, cinsiyet, siyasi düşünce, felsefi inanç, din, mezhep ve benzeri sebeplerle ayırım gözetilmeksizin kanun önünde eşit olduğunu, çocuklar, yaşlılar, engelliler, harf ve vazife şehitlerinin dul ve yetimleri ile malul ve gaziler için alınacak tedbirlerin eşitlik ilkesine aykırı sayılamayacağını hüküm altına alan 10. maddesi de yaşlı haklarının güvence altına alındığı bir diğer düzenlemedir. Söz konusu madde hükmünden de anlaşllabileceği üzere, toplumda dezavantajlı kabul edilen kesimlere yönelik pozitif ayrımcılık Anayasal düzeyde kabul edilmiş ve ayrıca devlet söz konusu ilkeyi yaşama geçirme bakımından yükümlü kılmıştır (Ulucan, 2014: 372; Evren, 2018: 157). Anayasada yer alan "sosyal bir hukuk devleti" (mad. 2), "kanun önünde eşitlik" (mad. 10) başlık düzenlemelerinin dışında, herkes gibi yaşlıların da sağlık hakkı (mad. 17) ve sosyal güvenlik hakkı (mad. 60) güvence altına alınmıştır. Anayasada sağlık hakkı, yaşam 
hakkının ayrılmaz bir parçası olarak düzenlenmiştir. Yine Anayasada herkesin yaşama, maddi ve manevi varlığını koruma ve geliştirme hakkına sahip olduğu, tıbbi zorunluluklar ve kanunda yazılı haller dışında, kişinin vücut bütünlügüne dokunulamayacağı, rızası olmadan bilimsel ve tıbbi deneylere tabi tutulamayacağı hüküm altına alınmıştır (mad. 17). Ayrıca Anayasada herkesin sağlıklı ve dengeli bir çevrede yaşama hakkına sahip olduğuna; çevreyi geliştirmenin, çevre sağlığını korumanın ve çevre kirlenmesini önlemenin Devletin ve vatandaşların ödevi olduğuna vurgu yapılmıştır (mad. 56). Anayasaya göre Devlet, herkesin hayatını, beden ve ruh sağlı̆̆ gücünde tasarruf ve verimi artırarak işbirliğini gerçekleştirmek amaciyla sağlık kuruluşlarını tek elden planlayıp hizmet vermesini düzenler. Devlet bu görevini kamu ve özel kesimlerdeki sağlık ve sosyal kurumlarından yararlanarak, onları denetleyerek yerine getirir. Sağlık hizmetlerinin yaygın bir şekilde yerine getirilmesi için kanunla genel sağlık sigortası kurulabilir (mad. 56). Yine T.C. Anayasasında ayrım yapılmaksızın herkesin sosyal güvenlik hakkına sahip olduğu belirtilerek, Devletin bu güvenliği sağlayacak gerekli tedbirleri alması ve teşkilatı kurması gerektiği hüküm altına alındığı gibi (mad. 60), sosyal güvenlik bakımından özel olarak korunması gerekenler tek tek sayılarak, yaşlıların devletçe korunması gerektiğine, yaşlılara devlet yardımı ve sağlanacak diğer haklar ve kolaylıkların kanunla düzenlenmesi gerektiğine vurgu yapılmıştır (mad. 61). Yine Anayasa'nın 61. maddesinde özel olarak korunması gereken diğer kesimler gibi yaşlıların da sosyal güvenliklerinin sağlanması için devletin gerekli teşkilat ve tesisleri kurması veya kurdurtması gerektiği hüküm altına alınmıştır. Ancak Anayasa'nın 65. maddesine göre devlet, söz konusu görevlerini sosyal ve ekonomik alanlarda Anayasa ile belirlenen diğer görevleri gibi, görevlerin amaçlarına uygun öncelikleri gözeterek malî kaynaklarının yeterliliği ölçüsünde yerine getirir. Son olarak yaşlılarla ilgili Anayasa hükümleri incelendiğinde, yaşlılığın kişilerin cezalarının Cumhurbaşkanınca hafifletilebileceği veya kaldırılabileceği bir neden olarak düzenleme konusu yapıldığı görülmektedir (mad. 104).

\section{B- Kanunlar}

Yaşı haklarının güvence altına alındığı Anayasa hükümlerine uygun olarak birçok kanunda yaşlıların korunmasına yönelik düzenlemelere yer verilmiştir. Söz konusu kanunlardan ilki, 24.05.1983 tarih ve 2828 sayılı Sosyal Hizmetler Kanunu'dur. Anayasanın 61. maddesine uygun olarak hazırlanmış olan Sosyal Hizmetler Kanunu'nun (R.G., T. 27.05.1983, S. 18059) amacı; korunmaya, bakıma ve yardıma ihtiyacı olan aile, çocuk, engelli, yaşlı ve diğer kişilere götürülen sosyal hizmetlere ve bu hizmetleri yürütmek üzere kurulan teşkilatın kuruluş, görev, yetki ve sorumlulukları ile faaliyet ve gelirlerine ait usul ve esasları düzenlemektir (mad. 1). Sosyal Hizmetler Kanunu'nun "engelli ve bakıma ihtiyacı olan engelli" kavramları ile "bakıma ihtiyacı olan yaşlı" kavramının tanımlandığı 3. maddesinde aynı zamanda bakım hizmeti veren sosyal hizmet kuruluşları da sıralanmıştır. Sosyal Hizmetler Kanunu'nun 4. maddesinde değinilen hususlardan biri de ihtiyacı olan engelli ve yaşlıların hayatlarını sağlık, huzur ve güven içinde sürdürmesi, ihtiyacı olan engellilerin toplum içinde kendi kendilerini idare edebilecek ve üretken hâle gelebilecek şekilde bakım ve rehabilitasyonlarının yapılması, bunlardan tedavisi mümkün olmayanların sürekli bakım altına alınması amacıyla gerekli her türlü tertip ve tedbir alınması gerektiğidir (mad. 4/1). 2828 sayılı Kanun ek madde 11'de de 3294 sayılı Sosyal Yardımlaşma ve Dayanışma Kanunu dışında sosyal yardım düzenlenmiştir. Söz konusu madde hükmüne göre sosyal güvenlik kuruluşlarının herhangi birisinden her ne ad altında olursa olsun bir gelir veya aylık hakkından yararlananlar ile uzun vadeli sigorta kolları açısından zorunlu olarak sigortalı olunması gereken bir işte çalışanlar hariç olmak kaydıyla, Aile, Çalışma ve Sosyal Hizmetler Bakanlığının sosyal hizmet kuruluşları ile Darülaceze Müessesesinde ücretsiz bakılan veya bakım ücreti Aile, Çalışma ve Sosyal Hizmetler Bakanlığı tarafından 
Uluslararası İlke ve Standartlar Bağlamında Yaşlı Hakları ve Sosyal Hizmet Uygulamaları

ödenerek, özel sosyal hizmet kuruluşlarında bakımı sağlanan ya da Aile, Çalışma ve Sosyal Hizmetler Bakanlığınca yardım yapılmak suretiyle desteklenen resmî sosyal hizmet kuruluşlarında verilen bakım hizmetinden yararlanıp da Aile, Çalışma ve Sosyal Hizmetler Bakanlığının sosyal hizmet kuruluşlarınca verilen bakım hizmetinden ücretsiz yararlanmaya ilişkin koşulları haiz olan yaşlılar ile engelli bireylere, her yıl merkezî yönetim bütçe kanunu ile belirlenecek miktar üzerinden hiçbir kesinti yapılmaksızın aylık net harçlık verilir." Söz konusu Kanuna istinaden çıkarılan Sosyal Hizmet Kuruluşlarında Bakımı Sağlanan Engelli ve Yaşlı Bireylere Harçlık Ödenmesine İlişkin Yönetmelik uyarınca söz konusu harçlık her yıl merkezî yönetim bütçe kanunu ile belirlenecek miktar üzerinden hiçbir kesinti yapılmaksızın ödenir (m. 5). 2828 sayılı Kanunda yaşlılara yönelik olarak öngörülmüş bir diğer düzenleme ise korunmaya ve bakıma alınmış olup, iş görme gücüne sahip ve istekli olan yaşlıların bulundukları sosyal hizmet kuruluşlarının uygun görülen hizmetlerinde haftada 40 saati geçmemek üzere tespit edilecek çalışma saatleri içinde, saat başına ücret ödenmek kaydıyla çalıştırılabileceklerine ilişkin 16. madde hükmüdür (mad.16/3). Benzer şekilde 2828 sayılı Kanun'un 27. maddesinde de yaşlılarla ilgili olarak sosyal hizmet kuruluşlarında muhafaza ve bakımlarına terkedilen şahıslara karşı herhangi bir suç işleyen kuruluş görevlileri hakkında işlenen suç nedeniyle genel hükümlere göre verilecek muvakkat hürriyeti bağlayıcı cezalar ile para cezalarının 1/3 oranında artırılarak hükmolunacağı öngörülmüştür. Yine 2828 sayılı Sosyal Hizmetler Kanunu'na göre bir kişiye bakım hizmeti verilebilmesi, Kanunda belirtilen diğer şartlar yanında, kişinin 65 yaşını doldurmuş olmasına bağlıdır (ek mad. 10).

Yaşlı haklarının güvence altına alındığı Anayasa hükümleri bağlamında ele alınması gereken bir diğer Kanun, yaşlılık sigortası adı altında yaşlıların sosyal güvenlik hakkını düzenleyen 31.05.2006 tarih ve 5510 sayılı Sosyal Sigortalar ve Genel Sağlık Sigortas1 Kanunu (R.G., T. 16.06.206, S. 26200)'dur (mad. 28-31). Söz konusu Kanunda yaşl1lık sigortası adı altında düzenlenmiş olan sosyal güvenlik ve sosyal güvenlik hakkı, “...toplumun parçası olan bireylere, gelirleri ne olursa olsun doğal bir olay olan yaşlılık ile hastalık, kaza, ölüm ve malullük gibi sosyal riskler karşısında asgari bir yaşam düzeyi sağlama amacına yöneliktir". Sosyal güvenlik kuruluşuna tabi olmayan ve muhtaç olan yaşlılara sosyal güvenlik hakkı bağlamında yapılması gereken sosyal yardımlar ise 3294 sayılı Sosyal Yardımlaşma ve Dayanışma Kanunu ile düzenleme konusu yapılmıştır. Yine sosyal yardım niteliğinde 65 yaşını doldurmuş olup kendisi ve eşine ait her tür aylık gelir tutarı asgari ücretin 1/3'ünden düşük olanlara 2022 sayılı 65 Yaşını Doldurmuş Muhtaç, Güçsüz ve Kimsesiz Türk Vatandaşlarına Aylık Bağlanması Hakkında Kanun ile aylık bağlanması öngörülmüştür.

Değinilen kanunlar dışında, yaşlı hakları konusunda 2005 tarih ve 5393 sayılı Belediye Kanunu (R.G., T. 13.07.2005, S. 25874), 22.11.2001 tarih ve 4721 sayılı Türk Medeni Kanunu (TMK) (R.G., T.08.12.2001, S. 24607), 5237 sayılı Türk Ceza Kanunu (TCK) (R.G., T. 12.10.2004, S. 25611), 13.12.2004 tarih ve 5275 sayılı Ceza ve Güvenlik Tedbirlerinin İnfazı Hakkında Kanun (R.G., T. 29.12.2004, S. 25685), 12.05 .1930 tarih ve 1632 sayılı Askeri Ceza Kanunu (R.G. T. 15.06.1930, S.1520)'da da çeşitli düzenlemelere yer verilmiştir. Nitekim Belediye Kanunu'nda belediye hizmetlerinin, vatandaşlara en yakın yerlerde ve en uygun yöntemlerle sunulması ve söz konusu hizmetlerin sunumunda engelli, yaşlı, düşkün ve dar gelirlilerin durumuna uygun yöntemlerin uygulanması gerektiği (mad. 14/4); belediyenin sağlık, eğitim, spor, çevre, sosyal hizmet ve yardım, kütüphane, park, trafik ve kültür hizmetleriyle yaşlılara, kadın ve çocuklara, engellilere, yoksul ve düşkünlere yönelik hizmetlerin yapılmasında beldede dayanışma ve katılımı sağlamak, hizmetlerde etkinlik, tasarruf ve verimliliği artırmak amacıyla gönüllü kişilerin katılımına yönelik programlar uygulayabileceği hüküm altına alınmıştır (mad. 77). 
TMK'nin 405. maddesinde ise akıl hastalığg veya akıl zayıflığı sebebiyle işlerini göremeyen veya korunması ve bakımı için kendisine sürekli yardım gereken ya da başkalarının güvenliğini tehlikeye sokan her erginin kısıtlanacağı, 408. maddesinde yaşlılığı, engelliliği, deneyimsizliği veya ağır hastalığı sebebiyle işlerini gerektiği gibi yönetemediğini ispat eden her erginin kısıtlanmasını isteyebileceği hüküm altına alınmıştır. Mali suistimali önlemeye yönelik benzer bir düzenlemeye Noterlik Kanunu Yönetmeliği'nde de yer verilmiştir (mad.91). Ayrıca TMK'de vasilikten kaçınma sebepleri başlığı altında vasiliği kabul etmeyebilecekleri belirtilen kişiler arasında yaşlılara ve engellilere de yer verilmiştir. Söz konusu madde hükmüne göre 60 yaşını doldurmuş olanlar ile bedensel engelleri veya sürekli hastalıkları nedeniyle vasilik görevini güçlükle yapabilecek olanlar söz konusu görevi kabul etmeyebilirler.

5237 sayılı Türk Ceza Kanuna göre daha önce hapis cezasına mahkum edilmemiş olmak koşuluyla, mahkum olunan 30 gün ve daha az süreli hapis cezası ile fiili işlediği tarihte 18 yaşını doldurmamış veya 65 yaşını bitirmiş bulunanların mahkum edildiği 1 yıl veya daha az süreli hapis cezası, birinci fikrada yazılı seçenek yaptırımlarından birine çevrilir (mad.50/3). Yine TCK'nin 51. maddesi uyarınca işlediği suçtan dolayı iki yıl veya daha az süreyle hapis cezasına mahkûm edilen kişinin cezası ertelenebilecek olup erteleme süresinin üst sınırı, fiil işlediği sırada 18 yaşını doldurmamış veya 65 yaşını bitirmiş olan kişiler bakımından 3 yıldır. TCK'nin 97. ve 98. maddelerinde, yaşı veya hastalığ dolayısıyla kendini idare edemeyecek durumda olduğu için koruma ve gözetim yükümlülüğü altında bulunan bir kimseyi kendi haline terk eden kişinin, 3 aydan 2 yıla kadar hapis cezasıyla ve yaşı, hastalığı veya yaralanması dolayısıyla ya da başka herhangi bir nedenle kendini idare edemeyecek durumda olan kimseye hal ve koşulların elverdiği ölçüde yardım etmeyen ya da durumu derhal ilgili makamlara bildirmeyen kişinin, 1 yıla kadar hapis veya adli para cezasıyla cezalandırılacağı hükümlerine yer verilmiştir (Evren, 2018: 142-143).

TCK’ye benzer şekilde, 5275 sayılı Ceza ve Güvenlik Tedbirlerinin İnfazı Hakkında Kanunun 110. maddesinde de kadın veya 65 yaşını bitirmiş kişilerin mahkûm oldukları altı ay, yetmiş yaşını bitirmiş kişilerin mahkûm oldukları bir yıl, yetmiş beş yaşını bitirmiş kişilerin mahkûm oldukları üç yıl veya daha az süreli hapis cezasının konutunda çektirilmesine hüküm veren mahkemece veya hükümlü başka bir yerde bulunuyorsa o yerde bulunan aynı derecedeki mahkemece karar verilebileceği hüküm altına alınmıştır. 1632 sayılı Askeri Ceza Kanunu'nun 47/A maddesinde ise; "hüküm zamanında yetmiş yaşına girmiş olanların mahkûm oldukları bir seneden az hapis cezalarının tecil olunabileceği” hükmü getirilmiştir.

Yaşlı hakları konusunda 05.11.2008 tarih ve 5809 sayılı Elektronik Haberleşme Kanunu (R.G., T. 10.11.2008, S. 27050 (Mükerrer)), 15.02.2011 tarih ve 6112 sayılı Radyo ve Televizyonların Kuruluş ve Yayın Hizmetleri Hakkında Kanun (R.G., T. 03.03.2011, S. 27863), 07.11.2013 tarih ve 6502 sayılı Tüketicinin Korunmas1 Hakkında Kanun (R.G., T. 28.11.2013, S. 28835), 04.04.2013 tarih ve 6458 say1l Yabancılar ve Uluslararası Koruma Kanunu (R.G., T. 11.04.2013, S.28615), 08.01.2002 tarih ve 4736 sayılı Kamu Kurum ve Kuruluşlarının Ürettikleri Mal ve Hizmet Tarifeleri ile Bazı Kanunlarda Değişiklik Yapılması Hakkında Kanun (R.G., T. 19.01.2002, S. 24645) gibi çeşitli kanunlarda da hükümler bulunmaktadır. Nitekim 5809 sayılı Kanunda elektronik haberleşme hizmetinin sunulması ve bununla ilgili olarak yapılacak düzenlemelerde teknolojik yeniliklerin kullanılması da dâhil olmak üzere engelli, yaşlı ve sosyal açıdan korunmaya muhtaç diğer kesimlerin özel ihtiyaçlarının dikkate alınması gerektiği hüküm altına alınmıştır (mad.4). 
6112 sayılı Kanunda ise engellilerin ve yaşlıların yayın hizmetlerine ve yeni teknolojilere erişimini kolaylaştırmak amacıyla gerekli tedbirlerin alınması ve teşvik edilmesi Radyo ve Televizyon Üst Kurulunun görevleri arasında sayılmıştır (mad. 37). 6502 sayılı Kanuna göre tüketiciyi aldatıcı veya onun tecrübe ve bilgi noksanlıklarını istismar edici, can ve mal güvenliğini tehlikeye düşürücü, şiddet hareketlerini ve suç işlemeyi özendirici, kamu sağlı̆̆ını bozucu, hastaları, yaşlıları, çocukları ve engellileri istismar edici ticari reklam yapılması yasaklanmıştır (mad. 61). 6458 sayılı Kanunda ciddi sağlık sorunları, yaş ve hamilelik durumu nedeniyle seyahat etmesi riskli görülen yabancılar hakkında sınır dış1 etme kararı verilemeyeceği hüküm altına alınmıştır (mad. 55). 4736 sayılı Kanuna göre Türk vatandaşı olan 65 yaş ve üzeri kişiler, demir yolları ve deniz yollarının şehir içi hatları ile belediyelere, belediyeler tarafindan kurulan şirketlere, birlik, müessese ve işletmelere veya belediyeler tarafından yetki verilen özel şahıs ya da şirketlere ait şehir içi toplu taşıma hizmetlerinden ücretsiz olarak yararlanırlar. Söz konusu kurum ve kuruluşlar 60-65 yaş arasında bulunan kişilerin toplu taşıma hizmetlerinden ücretsiz veya indirimli olarak yararlanmasını da sağlayabilirler.

\section{C- Cumhurbaşkanlığı Kararnameleri}

Anayasada 2017 yılında yapılan değişiklik ile başkanlık sistemine geçilmiş, bakanlıkların kurulması, kaldırılması, görevleri ve yetkileri, teşkilat yapısı ile merkez ve taşra teşkilatlarının kurulmasının Cumhurbaşkanlığı kararnamesiyle düzenleneceği hükmü yer almıştır (AY. mad. 106). Söz konusu düzenleme ile benimsenen yeni anayasal sistemde, KHK'lerin yerini Cumhurbaşkanlığı Kararnameleri almıştır. Anayasa'da tanımı olmamakla birlikte Cumhurbaşkanlığı Kararnamesi, Anayasa hükümlerine göre "yürütme yetkisine ilişkin olarak daha önce Bakanlar Kurulu Kararı, tüzük veya KHK'lerle düzenlenen hususlara benzer hususları düzenleyen ve fakat bakanların imzalarını değil sadece Cumhurbaşkanı'nın imzasını taşıyan yasal düzenleme aracı" şeklinde tanımlanabilir. Yeni Anayasal sistemde Bakanlar Kurulu bulunmadığından TBMM tarafından yürütme organına KHK çıkarma yetkisi verilmesi ve yürütme organınca KHK çıkarılması mümkün değildir. Anayasaya göre Cumhurbaşkanlığı Kararnameleri ile sosyal ve ekonomik haklar ve ödevler düzenleme konusu yapılabilir (Yıldırım, 2017: 13-28). Dolayısıyla bir sosyal ve ekonomik hak olarak yaşlı haklarına yönelik Cumhurbaşkanlığı Kararnamesi çıkarılabilecektir.

\section{D- Yönetmelikler}

Cumhurbaşkanı, bakanlıklar ve kamu tüzel kişileri kendi görev alanlarını ilgilendiren yasaların ve Cumhurbaşkanlığı kararnamelerinin uygulanmasını sağlamak üzere ve bunlara aykırı olmamak koşuluyla, yönetmelikler çıkarabilirler. Yaşlı haklarının ulusal hukuki dayanakları arasında özellikle Sosyal Hizmetler Kanunu hükümlerine uygun olarak yürürlüğe konulan Huzurevleri ile Huzurevleri Yaşlı Bakım ve Rehabilitasyon Merkezleri Yönetmeliği (R.G., T. 21.02.2001, S. 24325), Özel Huzurevleri ile Huzurevi Yaşlı Bakım Merkezleri Yönetmeliği (R.G., T. 07.08.2008, S. 26960), Yaşlı Hizmet Merkezlerinde Sunulacak Gündüzlü Bakım ile Evde Bakım Hizmetleri Hakkında Yönetmelik (R.G., T.07.08.2008, S.26970) ve Sosyal Hizmet Kuruluşlarında Bakımı Sağlanan Engelli ve Yaşlı Bireylere Harçlık Ödenmesine İlişkin Yönetmelik (R.G., T.31.01.2015, S.29253) önemli yere sahiptir.

Huzurevleri ile Huzurevleri Yaşlı Bakım ve Rehabilitasyon Merkezleri Yönetmeliğinin amacı, huzurevleri ile huzurevi yaşlı bakım ve rehabilitasyon merkezlerinde bakım görecek 60 yaş üzerindeki yaşlıların saptanması, bakım ve rehabilitasyon hizmetlerinden yararlandırılması, verilecek hizmetin tür ve niteliği ile işleyiş esaslarını belirlemek, 
personelin görev, yetki ve sorumluluklarını düzenlemektir (mad. 1). Söz konusu Yönetmelik; 60 yaş ve üzerindeki muhtaç yaşlıları korumak, bakmak, sosyal, psikolojik ve fiziksel gereksinimlerini karşılamak, sürekli bakıma ve rehabilitasyona gereksinim duyanlara bakım ve rehabilitasyon hizmeti vermekle görevli ve yükümlü olan Aile, Çalışma ve Sosyal Hizmetler Bakanlığına bağlı huzurevleri ile huzurevi yaşlı bakım ve rehabilitasyon merkezlerini kapsar (mad. 2).

Özel Huzurevleri ile Huzurevi Yaşlı Bakım Merkezleri Yönetmeliğinin amacı; gerçek kişiler ve özel hukuk tüzel kişileri tarafından açılacak huzurevi ile huzurevi yaşlı bakım merkezlerinin açılış işlemleri, hizmet standardı, personel durumu, işletilme koşulları, ücreti, denetimi, devri ve kapatılmasına yönelik usul ve esasları belirlemektir (mad. 1). Söz konusu Yönetmeliğin kapsamına, gerçek kişiler veya özel hukuk tüzel kişilerince açılan huzurevleri ile huzurevi yaşlı bakım merkezleri girer (mad. 2). Uygulamada özel huzurevi hizmeti veren kuruluşların dernek ve vakıflara, azınlıklara ya da gerçek kişilere ait özel kuruluşlar olduğu görülmektedir.

2828 sayılı Sosyal Hizmetler ve Çocuk Esirgeme Kurumu Kanunu'nun 4. maddesinin birinci fikrasının (a) bendine dayanılarak hazırlanan, Yaşlı Hizmet Merkezlerinde Sunulacak Gündüzlü Bakım ile Evde Bakım Hizmetleri Hakkında Yönetmeliğin amacı, huzurevi bakımını tercih etmeyen yaşlılar için gündüzlü bakım ve evde bakım hizmetlerinin niteliğini ve bu hizmetleri yerine getiren birim ve personele ilişkin usul ve esasları belirlemektir (mad. 1). Söz konusu yönetmeliğin kapsamına kamu kurum ve kuruluşları ile gerçek kişiler ve özel hukuk tüzel kişilerince açılacak yaşlı hizmet merkezleri (eski adıyla yaşlı dayanışma merkezi) tarafından yaşlılara verilecek gündüzlü bakım ile evde bakım hizmeti faaliyetleri girer (mad. 2).

2828 sayılı Sosyal Hizmetler Kanunu'nun ek 11. maddesine dayanılarak hazırlanan, Sosyal Hizmet Kuruluşlarında Bakımı Sağlanan Engelli ve Yaşlı Bireylere Harçlık Ödenmesine İlişkin Yönetmeliğin amacı, sosyal güvenlik kuruluşlarının herhangi birisinden her ne ad altında olursa olsun bir gelir veya aylık hakkından yararlananlar ile uzun vadeli sigorta kolları açısından zorunlu olarak sigortalı olunması gereken bir işte çalışanlar hariç olmak kaydıyla, AÇSHB'nin sosyal hizmet kuruluşları ile Darülaceze Müessesesinde ücretsiz bakılan veya bakım ücreti AÇSHB tarafindan ödenerek özel sosyal hizmet kuruluşlarında bakımı sağlanan ya da AÇSHB'ce yardım yapılmak suretiyle desteklenen resmî sosyal hizmet kuruluşlarında verilen bakım hizmetinden yararlanıp da AÇSHB'nin sosyal hizmet kuruluşlarınca verilen bakım hizmetinden ücretsiz yararlanmaya ilişsin koşulları haiz olan yaşlılara ve engelli bireylere aylık harçlık ödenmesine ilişkin usul ve esasları düzenlemektir (mad. 1).

Değinilen yönetmeliklere ilaveten yaşlılara ücretsiz veya indirimli seyahat imkanı sağlayan 4736 sayılı Kamu Kurum ve Kuruluşlarının Ürettikleri Mal ve Hizmet Tarifeleri ile Bazı Kanunlarda Değişiklik Yapılması Hakkında Kanun hükümlerine dayanılarak çıkarılan Ücretsiz veya İndirimli Seyahat Kartları Yönetmeliği (R.G., T. 04.03.2014, S. 28931) ile yaşlılara aşevi hizmeti sunan Vakıflar Yönetmeliği (R.G., T. 27.09.2008, S. 27010) de yaşlı hakları bağlamında önemli düzenlemelerdir.

Son olarak yaşı haklarının ulusal hukuki dayanakları ele alındığında, yaşlı haklarına ilişkin genelgeler ve tebliğler de yayınlandığı görülmektedir. Söz konusu genelge ve tebliğlere 2010/73 Sayılı Poliklinik Hizmetlerinde Öncelik Sırasına İlişkin Sağlık Bakanlığı Genelgesi (Yaşlılara Öncelik Verilmesine İlişkin Hizmet) ile Ulusal Meslek Standartlarına Dair Tebliğ ("Engelli ve Yaşlı Bakım Elemanı", "Engelli ve Yaşlı Bakım Koordinatörü", "Gerentolog”) örnek verilebilir. 


\section{IV- ULUSLARARASI VE ULUSAL DÜZENLEMELER BAĞLAMINDA YAŞLI HAKLARI}

Uluslararası ve ulusal düzenlemeler bağlamında yaşlılar, gereksinimleri doğrultusunda politik ve toplumsal yaşama katılım, eğitim ve kültür, eşit ve adil muamele görme, ayrımcılığa maruz kalmama, adil gelir ve sosyal güvenlik, yaşa bağlı bir engelle karşılaşmadan çalışma, gelir getirici faaliyetlerde bulunma, aile, konut ve barınma, güvenli bir çevrede yaşama, sosyal yardım ve sosyal hizmetlerden yararlanma, sağlık ve bakım haklarına sahiptirler (Dural ve Con, 2013: 485-490; Yaşlı Bakıcısı, 2019; Evren, 2018: 150151).

Değinilen haklardan politik ve toplumsal yaşama katılım hakkı bağlamında, yaşlılar refah düzeylerini doğrudan etkileyecek politikaların hazırlanması ve uygulanması aşamalarına aktif bir biçimde katılımda bulunmalıdır. Bilgi ve becerilerini genç kuşaklar ile paylaşmalıdır. Topluma hizmet etmek için çeşitli fursatlar geliştirebilmelidir. Kendi ilgi ve yeteneklerine uygun etkinliklerine gönüllü olarak katılımda bulunmalı ve hizmet edebilmelidir.

Eğitim hakkı en temel sosyal haklardan biridir. Eğitim ile kastedilen sadece örgün eğitim değildir. Eğitim hakkı, örgün eğitimle birlikte yaşam boyu öğrenmeyi de kapsamaktadır. Dolayısıyla yaşlıların da yaşlarına ve yeteneklerine uygun eğitim programlarına sahip olmaları gerekir. Bir insanın tüm yaşamı boyunca eğitim alma hakkının saklı kalması, hem teknolojik gelişmeler ve hem de bilimdeki ilerleme, bilgiye erişim konusunda yaşam boyu eğitime erişim bakımından önemlidir.

Her tür şiddet, istismar ve ayrımcılığa karşı korunma hakkı olarak da ifade edilen eşit ve adil muamele görme, ayrımcılığa maruz kalmama hakkı gereği, yaşlı bireyler itibar görmeli ve güven içerisinde yaşamalıdır. Bunun sağlanabilmesi için yaşlıların her tür şiddetten, sömürüden, fiziksel ya da zihinsel istismardan uzak tutulması gerektiği gibi, hizmetlerden yararlanırken yaş, cinsiyet, ırk, etnik köken, özür durumları ya da diğer konumları nedeniyle ayrım görmemesi de gerekir.

Adil gelir ve sosyal güvenlik hakkı gereği, her insanın insan onuruna yakışır bir yaşam sürdürebilmesi için ekonomik güvenceye sahip olması gerekmektedir. Bunun sağlanabilmesi için her yurttaş gibi yaşlıların da emeklilik maaşı ya da yaşlılık/yaşlı aylı̆̆ı şeklindeki gelirlerinin kendi yaşam standartlarına uygun, başka bir deyişle beslenme, barınma, giyim gibi temel gereksinimlerini karşılamak ve sağlık bakımından yararlanmak için yeterli olması ve sürekli olması da gerekir. Ayrıca yaşlılar değinilen gereksinimlerini karşılayabilmeleri için ailelerinden ve toplumun her kesiminden de destek almalıdırlar. Ayrıca adil gelir ve sosyal güvenlik hakkı gereği, yaşlıların sosyal hayata katılabilmesi için emekli maaşının çalışırken alınan ücretle uyumlu olması hususuna dikkat edilmesi gerekir.

Çalışma ve istihdam hakkı olarak da ifade edilen yaşa bağlı bir engelle karşılaşmadan çalışma, gelir getirici faaliyetlerde bulunma hakkı gereği, her yurttaş gibi yaşlılar da gelir getirici bir işte çalışabilmeli ya da toplumdaki diğer gelir getirici faaliyetlerden yararlanmalıdır. Bunun sağlanabilmesi için yaşlılara çalışma hakkının tanıması ve hatta devletin yaşlılara çalışma olanağı yaratması gereklidir. Özellikle yaşlılar gibi özel gruplar için hem grubun niteliğine uygun istihdam şekilleri yaratılmalı hem de var olan istihdama katılabilmeleri noktasında yaştan doğan ayrımcılıkla savaşılması gerekmektedir.

Sağlık hizmetlerinden yararlanma hakkı, her bireyin her yaş dönemindeki en temel sosyal haklarından biridir. Yaş ile birlikte artan süreğen rahatsızlıklar ya da bazı yetilerdeki kayıplar, bireylerin yaşlılık döneminde kendi varlıklarına hakim olup, rahat bir yaşam 
sürdürmelerini zorlaştırmaktadır. Sağlık sorunları yaşamak, bir yaşlının ekonomik durumundan sosyal yaşama katılımına kadar tüm alanları etkilediği için sağlık hizmetlerine ulaşım ve sağlık sorunlarına uygun olarak sunulmuş olanaklara kavuşabilme, yaşlılık döneminde yaşamsal öneme sahiptir.

Aile hakkı, yaşlıların kendi evlerinde aileleri içerisinde yaşamaya devam etmelerini ve aile içerisinde bakımının mümkün olmasını güvence altına alan bir haktır. Söz konusu hak bağlamında, yaşlısına bakan ailelere devlet tarafindan maddi destek verilmektedir. Zira maddi destek yoluyla, yaşlıların aileleri tarafından bakılması güvence altına alınmaya çalışılmaktadır.

Konut ve barınma hakkı gereği, yaşlıların sağlık durumlarına göre çeşitli düzenlemelerin yapılabileceği uygun konutlara sahip olmaları gerekmektedir. Böyle olmakla birlikte, yaşlı uyumlu konut projelerinin tüm yaşlılara değil, sadece üst düzey gelir grubundaki yaşlılara yönelik olduğu görülmektedir.

Güvenli bir çevrede yaşama hakkı gereği, yaşlıların bireysel tercihlerine uygun, güvenli bir çevrede yaşamaları sağlanmalıdır. Yaşadıkları çevre aynı zamanda onlara kapasitelerini geliştirebilecekleri firsatlar da sunmalıdır. Dolayısıyla yaşlıların mümkün olduğunca uzun süre kendi evlerinde ya da aile ortamlarında yaşamaları sağlanmalıdır.

Sosyal yardımlar, sosyal güvenlik hukukunun kapsamı dışında kalan ve ihtiyaç içinde bulunan ya da yoksulluğa düşen insanlara devlet veya hükmi şahıslarca yapılan karşılıksız nakdi ve/veya ayni bütün yardımlardır. Maddi karakterli ve vergilerle finanse edilen sosyal yardımlar, sosyal güvenlikte son a ğ olarak ve mevcut sosyal güvence sistemlerinin açıklarını kapatıcı bir tedbir olarak nitelenmektedir (Erkul, 1983: 36; Sözer, 1997: 31; Sözer, 1998: 30-31). Dolayısıyla ihtiyaç içindeki yaşlıların da sosyal yardım ve hizmetlerden yararlanmaları sağlanmalıdır.

Yaşlılar bakım hakkına sahiptir ve bu hakkın temel felsefesini yaşlıya saygı ve yaşlıyı anlamaya çalışma felsefesi oluşturmaktadır. Yaşlıların, sosyal ve zihinsel yönden desteklenecekleri, kendilerini geliştirebilecekleri, koruma ve rehabilitasyon hizmeti alabilecekleri, uygun kurumsal bakım modellerinden yararlanabilecekleri insana yakışır bir ortam gerekmektedir. Bu bağlamda yaşı birey tıbbi bakıma ilaveten hospis bakım, akut bakım, subakut bakım ve kronik bakım hakkına sahiptir.

\section{V- TÜRKIYE'DE YAPILAN SOSYAL HIZMET UYGULAMALARININ GENEL BİR DEĞERLENDIRMESİ}

Dünyada ve Türkiye'de yaşlılara yönelik sosyal hizmet uygulamaları incelendiğinde, yaşlı hakları içerisinde göreli olarak bakım hakkının ön plana çıktı̆̆ı, yaşlıların diğer gereksinimleri karşılanmakla birlikte daha çok bakım gereksinimini karşılamaya dönük kurumsal yapılanmaların tercih edildiği görülmektedir. Sosyal hizmet uygulamalarının yaşlı hakları bağlamında kurumsal yapılanması incelendiğinde ise, refah sistemlerine göre bir ayrım yapmaksızın hemen hemen tüm dünya ülkelerinde huzurevleri, bakım ve rehabilitasyon kuruluşlarının yaygın olduğu ve öncelikle yaşlıların bakım gereksiniminin karşılanmasına odaklanan söz konusu kuruluşların yaşlıların konut ve barınma, sağlık, güvenli bir çevrede yaşama sosyal yardım ve sosyal hizmetlerden yararlanma gibi gereksinimlerinin karşılanmasına ikincil amaç olarak yöneldikleri görülmektedir (Çağlar, 2017: 149-153). Söz konusu yönelim bağlamında yaşlıların bakım gereksiniminin karşılanması için fonksiyonel bağımsızlığın sürdürülebilirliğini sağlama amacını taşıyan hospis bakım, akut bakım, subakut bakım ve kronik bakım uygulamalarının yaygın olduğu görülmektedir. 
Hospis bakım kuruluşları, ölümü beklenen her yaşta bireye rahat, huzurlu ve onurlu bir ölüm sağlamak üzere yapılandırılmış, sosyal çalışmacıların yaşlı ve aileleriyle yakından ve en yoğun çalıştıkları hizmet birimleridir. Amacı rehabilitasyon, kompleks bir medikal bakım ve/veya yara bakımı olan subakut bakım ise uzun dönem bakım evlerinde kısa bir süre kalması planlanan yaşlı hastalara yönelik bir bakım türüdür. Kronik bakım ise toplumda yaşamı tek başına başaramayan yaşlılara uygulanan bakım türüdür. Dünyada kronik hastalarla yaşlılara dönük fizyolojik ve sağlık odaklı akut bakım hizmetleri, subakut bakım hizmetleri de yaygın olarak sunulmaktadır. Yaşlıların bakım gereksiniminin karşılanmasına yönelik söz konusu bakım hizmeti hastanelerin geriatrik ünitelerinde verildiği gibi doğrudan geriatri hastanelerinde de verilebilmektedir. Ayrıca yaşlıya bakım hizmeti verenleri dinlendirmek amacıyla geçici bakım verme hizmeti olarak ifade edilen dinlendirme bakımı da sunulmaktadır. Acil yardımın yaşlının yaşadığı yere ilk ulaştığı andan itibaren verilen hizmet ise hastane öncesi bakımdır. Demans ve alzheimerlı yaşlılara hizmet veren bellek klinikleri de önemli bir hizmet modelidir. Türkiye'de değinilen bakım modelleri bağlamında yapılan uygulamalar çok yeni olup sınırlı düzeyde hizmet vermektedir.

Değinilen bakım modelleri bağlamında hastanelerde ve ilgili bakım merkezlerinde sunulan bakım hizmetleri dışında, dünya uygulamaları incelendiğinde, yaşlılara bakım, konut, barınma ve güvenli bir çevrede yaşama gibi temel gereksinimleri bağlamında yaşlı bakım evleri (nursing home), korunmalı meskenler, huzurevi, güçsüzler yurdu, gündüz bakım merkezleri, yaşlı kreşleri, yaşı kulüpleri, yaşlı apartmanları ve yaşlı köyleri gibi sosyal hizmet kuruluşları tarafından da çeşitli hizmetler sunulduğu görülmektedir. Söz konusu kuruluşlardan yaşlı bakım evleri, kendilerini idare edemeyecek kadar güçsüzleşen ve bakıma gereksinim duyan yalnız olan yaşlılara, engelliliği ya da işlev bozukluğu bulunan yaşlılara bakım ve rehabilitasyon hizmeti verirken, korunmalı meskenler ise normal evlerde yaşayamayacak durumdaki yaşlılar için yapılmış ve onların yetersizliklerine ve özel gereksinimlerine göre düzenlenmiş yapılar olarak karşımıza çıkmaktadır. Yine değinilen kuruluşlardan huzurevi, yaşı ve güçsüzlüğü nedeniyle yalnız yaşayamayan ya da korumalı meskenlerde barınamayan yaşlılara toplu hizmet veren ve gerektiğinde sağlık hizmeti de verilen yatılı sosyal hizmet kuruluşu iken, güçsüzler yurdu ise huzurevlerine benzemekle birlikte huzurevlerinden farklı olarak herhangi bir sosyal güvencesi, bakacak kimsesi ve gidecek yeri olmayan, yoksul yaşlılara devlet desteği ile bakım hizmeti veren yatılı sosyal hizmet kuruluşudur. Gündüzlü bakım merkezleri işlevselliği azalmış, engelli, kronik rahatsızlığı ve rehabilitasyona gereksinimi olan yaşlıların işlevselliğini ve bağımsızlığını artırıcı rolü olan bir diğer yaşı hizmet modelidir. Gündüzlü bakım merkezlerinin en önemli özelliği, sağlık, beslenme, rehabilitasyon, diyet, kişisel bakım, hukuksal ve mali sorunlarını çözme, boş zamanlarını değerlendirme gibi yaşlıların günlük yaşantılarında bir dizi program ve olanak sunarak, sorunlarını çözmelerine yardım etmektedir. Yaşlı kreşleri, yatağa bağlı olmayan ancak günlük yaşamında başkalarına bağımlı olan ve gündüz kendilerine bakacak yakını olmayan yaşlı kişiler için açılmış kuruluşlardır. Yaşlı kreşlerinden 60 yaş ve üzeri bulaşıcı hastalığı olmayan, yatağa bağımlı olmayan ve engelli olmayan demanslı yaşlılar yararlanmaktadır. Yaşlı kulüpleri, sağlıklı ve aktif yaşlıların boş zamanlarını değerlendirebilecekleri yaygın olarak yerel yönetimlerce organize edilip hizmet veren kuruluşlardır. Yaşlı apartmanları ve yaşlı köyleri ise yalnız yaşamak zorunda kalan ancak kendi yaş grubundan bireylerle aynı ortamda olma isteğine sahip olmak isteyip kurum bakımını istemeyen yaşlıların toplum içinde, güvenli ve korumalı bir ortamda yaşamalarına yardımcı olabilecek iki ayrı hizmet modelidir. Ülkemizde yaşlıların temel gereksinimleri bağlamında sahip oldukları haklar doğrultusunda yararlandıkları sosyal hizmetler incelendiğinde ise, ağırlıklı olarak söz konusu hizmetlerin huzurevleri, yaşlı bakım ve rehabilitasyon merkezleri, güçsüzler yurdu ve yaşlı hizmet merkezleri tarafından 
sunulduğu görülmektedir. Söz konusu kuruluşlarca sunulan hizmetler dışında ayrıca yaşlılara evde bakım hizmeti de verilmektedir (Önal Dölek, 2012: 100; Çağlar, 2017: 173192).

Dünyada yaşlıların temel gereksinimleri bağlamında sunulan hizmetler incelendiğinde, yukarıda değinilenler dışında ayrıca yalnız yaşayan tüm yaşlıların elektrik, doğalgaz ve su faturalarının devlet tarafından karşılanması, şehir içi ücretsiz ulaşım ve şehir dışı ulaşım kolaylıkları, ulusal gazetelerin ücretsiz dağıtımı, ilk yardım merkezlerinde 24 saat sürekli telefon iletişiminin sağlanması, kültür sanat etkinliklerinden az ücretle ya da indirimli yararlanma, dul, evlenmemiş ve bekâr yaşlılara sosyal yardım desteği yapılması, geliri olmayan yaşlılara yaşlılık aylığı adı altında aylık bağlanması, düzenli olarak yaşlı ziyaretlerinin yapılması gibi hizmetlerin de sunulduğu görülmektedir (Çamur Duyan ve Önal Dölek, 2013: 99). Yaşlılara sunulan söz konusu hizmetlerden şehir içi ücretsiz ulaşım ve şehir dışı ulaşım kolaylıkları, kültür sanat etkinliklerinden az ücretle ya da indirimli yararlanma, yaşlılık aylığı bağlanması hizmet ve yardımlar Türkiye'de de uygulanmaktadır. Türkiye'de ayrıca yaygın olarak huzurevleri aracılığıyla yaşlılara hizmet sunan belediyeler, farklı biçimlerde yaşlılara psikolojik destek hizmetleri, sağlık hizmetleri, rehberlik, refakat ve danışmanlık hizmetleri, sosyal ve kültürel etkinlikler, temizlik ve bakım hizmetleri, her türlü ev içi tamiratı, ekonomik destek hizmetleri, öncelikli hizmet kartı, acil yardım hizmetleri, yaşlı serbest kartı, hemşirelik hizmeti, su ve vergilerde indirim hizmetleri gerçekleştirmektedirler.

Türkiye'de sosyal hizmet uygulamaları bakımından başat kuruluşlar olan Aile, Çalışma ve Sosyal Hizmetler Bakanlığı ile belediyeler dışında, sivil toplum örgütlerince de yaşlılara yaygın olarak sağlık, dinlenme, tatil, boş zaman değerlendirme, beceri ve hobi kazandırma kursları niteliğinde çeşitli hizmetler sunulmaktadır. Ayrıca Türkiye'de yaşlılık alanında faaliyette bulunan çok sayıda dernek, vakıf, araştırma ve uygulama merkezi de mevcuttur. Yaşlılık alanında faaliyet gösteren söz konusu kuruluşlar, yaşlılıkla ilgili bilgi ve çalışmaları sürekli olarak yenilemek ve birleştirmek, politikalar üretmek, sorunlara çözüm bulmak ve farkındalık oluşturmak gibi amaçlarla kurulmuştur. 1998-2013 tarihleri arasında kurulan Yaşlı Sorunları Araştırma Derneği, Geriatrik Bilimler Araştırma ve Uygulama Merkezi-GEBAM, Türk Geriatri Vakfi, Türk Geriatri Derneği, Özel Huzurevi Dinlenme ve Bakımevleri Dayanışma Derneği, Akademik Geriatri Derneği, Geriatri Fizyoterapistler Derneği, Alzheimer Derneği, Ulusal Sosyal ve Uygulamalı Gerontoloji Derneği, Yaşlılık Araştırmaları Merkezi, Ege Geriatri Derneği, Yaşlılarla Dayanışma Derneği, Yaşlı ve Engelliler Eğitim, Araştırma ve Bakım Vakfı, Türkiye Osteoporoz Derneği, Dünya Yaşlanma Konseyi (DÜNYAK), Huzurevleri Kurma ve Yaşatma Derneği, Türkiye İleri Yaşlılık Araştırma Merkezi, Yaşlılık Çalışmaları Uygulama ve Araştırma Merkezi, Geriatri ve Gerontoloji Derneği, Geriatri Hemşireliği Derneği ve Yaşlı Hakları Derneği birçok dernek ve vakıf da yaşlılara dönük hizmet vermektedir (Özkul ve Kalaycı, 2015: 268).

\section{SONUÇ}

Tüm dünyada nüfusun yaşlanmakta oluşu, yaşlılığı, yaratacağı sorunların azaltılması noktasında ekonomik, sağlık ve sosyal politikalar geliştirilmesi ve gerekli yasal düzenlemelerin yapılması bağlamında uluslararası kuruluşların, devletlerin ve bilimsel çalışmaların gündemine taşımıştır. Söz konusu gelişmeler bağlamında, günümüzde yaşlılar geçmişte hiç olmadığı kadar özel olarak korunması gereken bir kesim olarak algılanmakta ve sahip oldukları haklar gerek uluslararası gerekse de ulusal düzenlemelerle güvence altına alınmaya çalışılmaktadır.

Uluslararası düzenlemeler ve çalışmalar incelendiğinde, yaşlıların özel olarak korunması gereken diğer kesimlere göre korunmalarına yönelik çalışmaların göreli olarak çok daha 
yeni ve daha sınırlı düzeyde olduğu görülmektedir. Yaşlıların korunmasına yönelik ilk uluslararası girişim, BM tarafından 1982 yılında Viyana'da yapılan Dünya Yaşlılık Konferansı ile başlatılmıştır. Söz konusu çalışmayı Avrupa Konseyi, AB ve ÜÇO tarafından yapılan çalışmalar takip etmiştir. Birçok uluslararası kuruluşun yaptığı düzenlemeye konu olmasına rağmen, halihazırda doğrudan yaşlılara yönelik uluslararası nitelikte bir sözleşme yapılmamış olması, yaşlıların sahip oldukları hakların güvence altına alınabilmesi noktasında çok önemli bir eksikliktir.

Türkiye'de yaşlıların özel olarak korunmasına yönelik mevzuat incelendiğinde ise başta Anayasa olmak üzere birçok kanunda yaşlılara yönelik özel hükümlere yer verildiği görülmektedir. Hiç kuşkusuz söz konusu düzenlemelerden, özel olarak korunması gereken diğer kesimlerle birlikte yaşlıların da korunmasına yönelik özel hükümler ihtiva eden 2828 sayılı Sosyal Hizmetler Kanunu diğer düzenlemelerden ayrılarak öne çıkmaktadır. Böyle olmakla birlikte Sosyal Hizmetler Kanunu'nun hem sosyal hizmetlerdeki yeni kurumsal yapılanma hem de yaşlı haklarının güvence altına alınması bağlamında yeniden düzenlenmesi gerektiği açıktır.

Uluslararası ve ulusal düzenlemelerde yaşlı hakları olarak sayılan politik ve toplumsal yaşama katılım, eğitim ve kültür, eşit ve adil muamele görme, ayrımcılığa maruz kalmama, adil gelir ve sosyal güvenlik, yaşa bağlı bir engelle karşılaşmadan çalışma, gelir getirici faaliyetlerde bulunma, aile, konut ve barınma, güvenli bir çevrede yaşama, sosyal yardım ve sosyal hizmetlerden yararlanma, sağlık ve bakım hakkı gibi haklar tüm sosyal ve ekonomik haklar gibi aslında bir insan hakkıdır. Yaşlılar temelini insan onurunun oluşturduğu değinilen haklara insan olmaları sebebiyle sahiptirler. Söz konusu haklar aynı zamanda yaşlıların gereksinimlerinin karşılanmasına yasal dayanak sağladığı için de önem arz etmektedir. Ancak değinilen haklardan özellikle sosyal yardım ve hizmetlerden yararlanma, sosyal güvenlik, sağlık ve bakım hakkına yaşlılar, içinde bulundukları koşullar nedeniyle çok daha fazla ihtiyaç duymaktadır. Hiç kuşkusuz gereksinimleri bağlamında söz konusu haklar ön plana çıksa da yaşlıların insan onuruna yaraşır bir şekilde yaşamlarını sürdürebilmeleri noktasında tüm sosyal ve ekonomik haklara sahip olma bakımından pozitif ayrımcılık kapsamında değerlendirilmeleri gerektiği açıktır. Dolayısıyla yaşlılara yönelik tüm politika ve düzenlemelerin pozitif ayrımcılık kapsamında ve temelini insan onurundan alan insan haklarına dayalı hak temelli bir anlayışla geliştirilmesi ve uygulamaların da değinildiği gibi hak temelli bir anlayışla yapılması gerekmektedir.

\section{Kaynakça}

Arpacı, F. (2005). Farklı Boyutlarıyla Yaşlılık. Ankara: Türkiye İşçi Emeklileri Derneği Eğitim ve Kültür Yayınları.

BM Enformasyon Merkezi (2007). Dünya Toplumsal Kalkınma Zirve Toplantısı Eylem Program1. [http://www.unicankara.org.tr/doc_ pdf/kop_deklar.pdf]. (Erişim: 21 Mart 2019).

BM (2019). Birleşmiş Milletler Binyıl Bildirgesi. [http://www.unicankara.org.tr/doc pdf/mill_decl_turkce.pdf]. (Erişim: 21 Mart 2019).

Çağlar, T. (2017). Yaşlı Bakımı Modeller ve Uygulamalar. 1. Bask1. Ankara: Nika Yayınevi.
Çamur, D. G. ve Dölek, Ö. B. (2013). Özürlü ve Yaşlilara Yönelik Sosyal Hizmet Kuruluşları. Sosyal Hizmet Kuruluşları (Ed. İ. Tomanbay ve N. Gökçek Karaca). Eskişehir: Anadolu Üniversitesi Yayınları No: 2873. Açıköğretim Fakültesi Yayınları. No: 1830.

Dural, B. ve Con, G. (2011). Türkiye'de Sosyal Devlet ve Yaşlı Hakları Üzerine Bir İnceleme. Sosyal Haklar Uluslararası Sempozyumu III Bildiriler. Kocaeli: Petrol-İş Yayınları.

Er, D. (2009). Psiko-Sosyal Açıdan Yaşlılık. Firat Sağllk Hizmetleri Dergisi. 1.131-144.

Erkul, İ. (1983). Sosyal Politika Dersleri. C.I. İstanbul. 
Emiroğlu, V. (1995). Yaşlılık ve Yaşlının Sosyal Uуumu. Genişletilmiş İkinci Baskı. Ankara. Şafak Matbaacılık.

Evren, Ç. C. (2018). Hukukta Yaşlı ve Yaşlılara Sunulan Sosyal Hizmetlerin İdare Hukuku Açısından Değerlendirilmesi. Ankara Hacı Bayram Veli Üniversitesi Hukuk Fakültesi Dergisi. 22 (2). 137-183. [http://webftp. gazi.edu.tr/hukuk/dergi/22_2_5.pdf]. (Erişim: 24 Mart 2019).

Gökçek Karaca, N. (2016). Bakım Hizmeti Gerektiren Birey. Bakım Elemanı Yetiştirme ve Geliştirme I. Anadolu Üniversitesi Yayınları. No: 3184. AÖF Yayınları. No: 2070. 34-67.

Görpelioğlu, S. (2009). Yaşlılık ve Getirdiği Sorunlar. Adl Eylül: Sağlık Bilimlerinde Yaşlılık (Ed. N. Gacar). İstanbul: Nobel Tip Kitapevi.

Karacan, E. (2017). Sosyal Politika Kapsamında Türkiye'de Yaşlı Nüfus: Sorunlar ve Çözüm Önerileri. Uluslararası Sosyal Araştırmalar Dergisi. 10(49). 637-644.

Karahan, A. ve Güven, S. (2002). Yaşlilıkta Evde Bakım. Turkish Journal of Geriatrics. 5(4). 155-159.

Karataş, Z. (2011). Evde Bakım Hizmeti Sunan Aile Bireyi Bakıcıların Moral ve Manevi Değerlerinin Başa Çıkmadaki Etkisi. Yüksek Lisans Tezi. Rize: Rize Üniversitesi Sosyal Bilimler Enstitüsü. [http://www.manevisosyalhizmet.com/wp-content/uploads/2013/03

/312309_tez.pdf]. (Erişim: 04 Ocak 2013).

Mertoğlu, M. (2013). Türkiye ve Dünyada Yaşlı Hakları ile İlgili Çalışma ve Yasal Düzenlemeler. Fasikül. 5(42). 11-14.

Önal Dölek, B. (2012). Evde ve Kurumda Uzun Dönemli Bakım. Klinik Gelişim Dergisi. 25(3). 95-99. [http://www.klinikgelisim.org.tr/kg_25_ 3/16.pdf]. (Erişim: 06 Mayıs 2019).

Özgür, Ö. ve Sabbağ, Ç. (2014). Kırsal Alanda Yaşlılık Adlyaman Samsat Örneği. Ankara: SABEV Yayınlar: 48. Araştırma Dizisi: 1.
Özkul, M. ve Kalaycı, I. (2015). Türkiye'de Yaşlılık Çalışmaları. Sosyoloji Konferansları. 52(2). 259-290.

Sözer, A. N. (1997). Sosyal Devlet Uygulamaları. İzmir: Türkiye İşçi Emeklileri Cemiyeti Yayınları.

Sözer, A. N. (1998). Türkiye'de Sosyal Hukuk. II. Baskı, İzmir: Barış Yayınları.

Tufan, İ. (2002). Antik Çağdan Günümüze Yaşlılık. İstanbul: Aykırı Yayıncılık.

TÜIK (2017). İstatistiklerle Yaşlılar. Haber Bülteni.[http://www.tuik.gov.tr/PreHaberBulten leri.do?id=24644]. (Erişim: 21 Mart 2019).

UÇÖ (2019). İnsana Yakışır İşin Merkezindeki Konu: Toplumsal Cinsiyet Eşitliği.[https://www.ilo.org/wcmsp5/groups/pu blic/@dgreports/@gender/documents/publicati on/wcms_120431 pdf]. (Erişim: 21 Mart 2019).

Ulucan D. (2014). Eşitlik İlkesi ve Pozitif Ayrımc1lı. Dokuz Eylül Üniversitesi Hukuk Fakültesi Dergisi.15 (özel). 369-383.

Yaşlı Bakıcısı (2019). Yaşlı Hakları. [http://www.yaslibakicisi.net/yaslibakimi10072-Yasli-Haklari.html]. (Erişim: 21 Mart 2019).

Yıldırım, T. (2017). Cumhurbaşkanlığ Kararnameleri. Marmara Üniversitesi Hukuk Fakültesi Hukuk Araştırmaları Dergisi. 23(2). 13-28. [http://dergipark.gov.tr/download/ article-file/456806]. (Erişim: 08 Kasım 2018).

Y1lmazer, A. (2013). Dünyada ve Türkiye'de Yaşlılarda Demografik Değişiklikler. Yaşlılarda Güncel Sağlık Sorunları ve Bakımı (Ed. Altındiş M.). 1-8. İstanbul: İstanbul Tıp Kitapevi.

World Health Organization (2017). Definition of an Older or Elderly Person. [http://www.who.int]. (Erişim: 24 Şubat 2019) 